\title{
Life cycle environmental impacts and costs of beer production and consumption in the UK
}

\author{
David Amienyo $^{1}$ - Adisa Azapagic ${ }^{1}$ \\ Received: 20 March 2015 / Accepted: 2 January 2016 / Published online: 2 February 2016 \\ (C) The Author(s) 2016. This article is published with open access at Springerlink.com
}

\begin{abstract}
Purpose Global beer consumption is growing steadily and has recently reached 187.37 billion litres per year. The UK ranked 8 th in the world, with 4.5 billion litres of beer produced annually. This paper considers life cycle environmental impacts and costs of beer production and consumption in the UK which are currently unknown. The analysis is carried out for two functional units: (i) production and consumption of 11 of beer at home and (ii) annual production and consumption of beer in the UK. The system boundary is from cradle to grave.

Methods Life cycle impacts have been estimated following the guidelines in ISO 14040/44; the methodology for life cycle costing is congruent with the LCA approach. Primary data have been obtained from a beer manufacturer; secondary data are sourced from the $\mathrm{CCaLC}$, Ecoinvent and $\mathrm{GaBi}$ databases. $\mathrm{GaBi} 4.3$ has been used for LCA modelling and the environmental impacts have been estimated according to the $\mathrm{CML}$ 2001 method.

Results and discussion Depending on the type of packaging (glass bottles, aluminium and steel cans), 11 of beer requires for example 10.3-17.5 MJ of primary energy and 41.2-41.81 of water, emits $510-842 \mathrm{~g}$ of $\mathrm{CO}_{2}$ eq. and has the life cycle
\end{abstract}

Responsible editor: Almudena Hospido

Electronic supplementary material The online version of this article (doi:10.1007/s11367-016-1028-6) contains supplementary material, which is available to authorized users.

Adisa Azapagic

adisa.azapagic@manchester.ac.uk

1 School of Chemical Engineering and Analytical Science, The University of Manchester, Room C16, The Mill, Sackville Street, M13 9PL Manchester, UK costs of $12.72-14.37$ pence. Extrapolating the results to the annual consumption of beer in the UK translates to a primary energy demand of over $49,600 \mathrm{TJ}(0.56 \%$ of UK primary energy consumption), water consumption of $1.85 \mathrm{bn} \mathrm{hl}$ (5.3\% of UK demand), emissions of $2.16 \mathrm{mt} \mathrm{CO}_{2}$ eq. ( $0.85 \%$ of UK emissions) and the life cycle costs of $£ 553$ million ( $3.2 \%$ of UK beer market value). Production of raw materials is the main hotspot, contributing from 47 to $63 \%$ to the impacts and $67 \%$ to the life cycle costs. The packaging adds 19 to $46 \%$ to the impacts and $13 \%$ to the costs.

Conclusions Beer in steel cans has the lowest impacts for five out of 12 impact categories considered: primary energy demand, depletion of abiotic resources, acidification, marine and freshwater toxicity. Bottled beer is the worst option for nine impact categories, including global warming and primary energy demand, but it has the lowest human toxicity potential. Beer in aluminium cans is the best option for ozone layer depletion and photochemical smog but has the highest human and marine toxicity potentials.

Keywords Beer $\cdot$ Climate change $\cdot$ Environmental impacts . Life cycle assessment $\cdot$ Life cycle costs $\cdot$ Packaging

\section{Introduction}

Global beer consumption has been growing steadily over the past decades and in 2012 it reached 187.37 billion $\left(10^{9}\right)$ litres (Kirin 2014), equivalent to 568 billion $33 \mathrm{cl}$ bottles. China is the largest beer-consuming country in the world with $23.6 \%$ share of the global market, followed by the USA, with roughly half of that. The UK is ranked 8th (Kirin 2014) with 4.5 bn litres of beer produced in 2014 (BBPA 2015), making it the largest alcoholic drinks sector in the country (Fig. 1). Half of the total beer produced in the UK is consumed in on-trade 


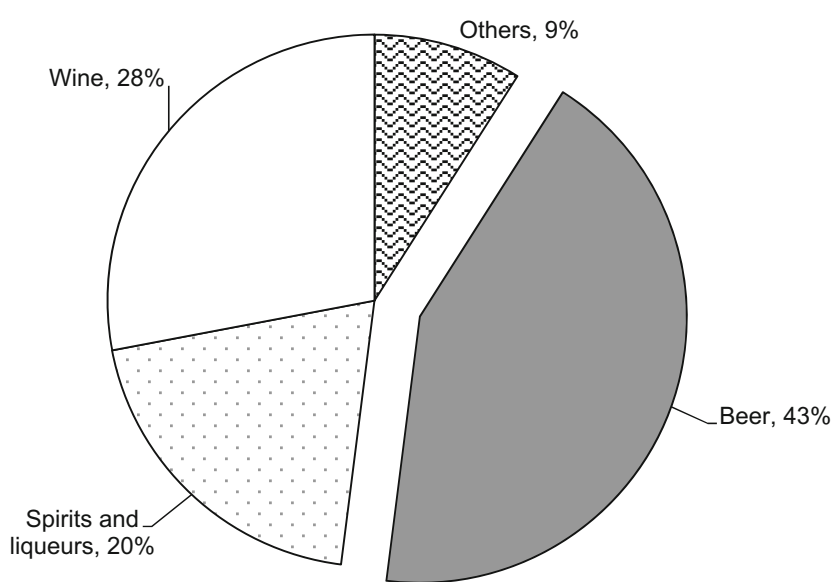

Fig. 1 UK alcoholic drinks sector by value (Key Note 2009)

outlets (bars, restaurants and other entertainment venues) and the remaining half is bought off-trade (off-licence shops, supermarkets and other retailers) for home consumption (BBPA 2015). The UK beer market was worth an estimated $£ 17.12$ billion (retail selling price) in 2013 (Key Note 2014).

There are several studies of life cycle environmental impacts of beer produced in different countries, including Australia (Narayanaswamy et al. 2004), Greece (Koroneos et al. 2005), Italy (Cordella et al. 2008), Spain (Hospido et al. 2005), Japan (Takamoto et al. 2004) and USA (Climate Conservancy 2008). Some studies considered beer production in whole regions, including the Nordic countries (Talve 2001), Europe and North America (BIER 2012). The assumptions and system boundaries in the studies vary widely, leading to significant differences in the impacts. For example, according to Talve (2001), the agricultural production of beer ingredients contributes almost $80 \%$ to the (weighted) environmental impacts, followed by transport ( $8 \%$ ) and production of auxiliary materials $(6 \%)$ and beer $(5 \%)$. On the other hand, Koroneos et al. (2005) found that the bottle production was the highest contributor (up to $94 \%$ ) to the impacts while Hospido et al. (2005) reported that the production of packaging as well as the cultivation of ingredients and transport were responsible for the largest portion of impacts. The inclusion of different environmental impacts and the methods used to estimate them also varies across the studies, which makes crosscomparisons difficult. Unsurprisingly, the global warming potential (GWP) is considered in all studies but the results range widely, not only across different studies but also within a study. For example, BIER (2012) estimated the GWP of beer in Europe at $139.6 \mathrm{~g} \mathrm{CO}_{2}$ eq. $/ 33 \mathrm{cl}$ bottle and of that in North America at $319.4 \mathrm{~g} \mathrm{CO}_{2}$ eq. $/ 35.5 \mathrm{cl}$ aluminium can, more than a factor of two difference. The study found that for the European beer barley malt contributed $39 \%$ to the GWP, followed by beer production (25\%), glass bottle and transport (13\% each). In North America, the aluminium can comprised $41 \%$ of the total impact, followed by the malt (33\%), beer production (12\%) and transportation (8\%). The GWP across all the studies ranged from $400-1475 \mathrm{~g} \mathrm{CO}_{2}$ eq./1 of beer.

As far as we are aware, there are no studies of environmental impacts of beer production and consumption in the UK. The only information that exists is that in 2003/2004 the UK beer sector contributed $0.96 \%$ to the UK GHG emissions (Garnett 2007) and around 470,000 tonnes ${ }^{1}$ of household packaging waste (Jenkin 2010). The other impacts remain largely unknown. Therefore, this paper sets out to estimate the life cycle environmental impacts of beer production and consumption in the UK. In addition to the impacts, the study also considers life cycle costs (LCC) in the beer supply chain. To our knowledge, this is the first study of LCC for beer globally.

The next section details the methodology and data used. This is followed in section 3 by discussion of the results, including comparisons with some of the aforementioned studies and possible improvement opportunities. The conclusions are summarised in section 4.

\section{Methodology}

The environmental impacts of beer have been estimated using life cycle assessment (LCA), according to the ISO 14040 and 14044 methodology (ISO 2006a, b). The LCC have been assessed following the approach in Hunkeler et al. (2008) and Swarr et al. (2011). The following is included in the estimations:

$\mathrm{LCC}_{\mathrm{Beer}}=C_{\mathrm{RM}}+C_{\mathrm{PR}}+C_{\mathrm{P}}+C_{\mathrm{T}}+C_{\mathrm{W}}$

where:

$\mathrm{LCC}_{\text {Beer }}$ life cycle costs of producing 11 of beer $(£ / 1)$

$C_{\mathrm{RM}}$ costs of raw materials $(£ / 1)$

$C_{\mathrm{PR}}$ costs of beer production $(£ / 1)$

$C_{\mathrm{P}}$ costs of packaging $(£ / 1)$

$C_{\mathrm{T}}$ transportation costs for raw materials, packaging, beer to retailer and post-consumer waste $(£ / 1)$

$C_{\mathrm{W}}$ costs of post-consumer waste disposal (£/l)

\subsection{Goal and scope definition}

The goal of the study is the estimation of life cycle environmental impacts and costs of beer produced and consumed in the UK. The study is divided into two parts: first, the impacts and costs are estimated at the consumer level with the aim of providing information to the consumer on the environmental impacts and costs of beer consumption. For these purposes, the functional unit is defined as the production and consumption of 1 l of beer at home. The second part of the study

\footnotetext{
${ }^{1}$ This estimate includes cider.
} 
considers the impacts and costs for the annual consumption of beer in the UK, aiming to inform the industry and policy makers on the total contribution of beer to the UK economy and environmental impacts. For this part of the analysis, the functional unit is defined as annual production and consumption of beer in the UK.

The study at the consumer level is related to the off-trade consumption while the sectoral study considers both on-trade and off-trade markets. We first focus on the functional unit at the consumer level; the assumptions and results for the sectoral analysis are discussed in Section 3.6.

As shown in Fig. 2, the system boundary of the study at the consumer level is from cradle to grave, comprising the following stages:
- raw materials: cultivation of barley and hops, production of barley malt, manufacture of sodium hydroxide, sulphuric acid, carbon dioxide and other auxiliary materials;

- manufacturing: electricity and material inputs for the beer production including grist preparation and milling, fermentation, carbonation, storage, filtration and filling;

- packaging: material and energy inputs for the manufacture of glass bottles (with steel bottle tops and multi-pack cardboard crates in which bottled beer is typical sold), aluminium and steel cans;

- retail and consumption: refrigerated storage of beer at retailer (only as part of sensitivity analysis) and postconsumer waste generated after consumption;

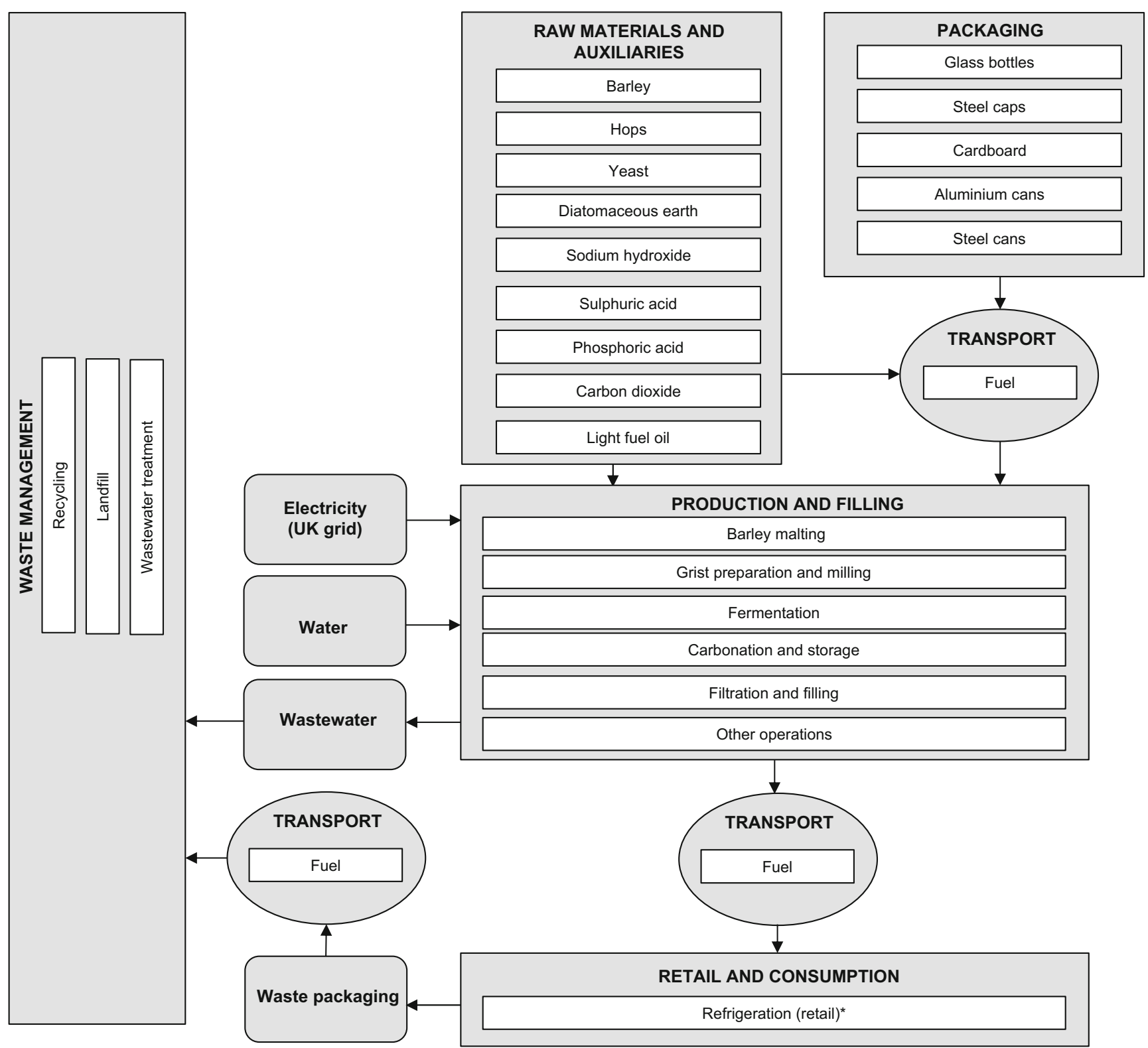

Fig. 2 The life cycle of beer considered in this study. [*Refrigeration at retailer considered only as part of sensitivity analysis] 
- waste management: treatment of wastewater from the beer production process, recycling and disposal of in-process and post-consumer waste streams; and

- transport: all transport of packaging materials, beer and waste.

The following is excluded from the analysis:

- production of secondary and tertiary packaging for the cans owing to a lack of data; furthermore, their contribution to the total GWP of beer was found to be insignificant $(<1 \%)$ in a study by the beer industry (BIER 2012) so that it is assumed that their contribution to other impacts would also be small;

- consumer transport to retailer because of uncertainties associated with allocation of impacts to beer relative to other items purchased at the same time; this is also congruent with the PAS 2050 standard (BSI 2011);

- refrigeration of beer at home, assuming that beer is consumed shortly after the purchase; even if refrigeration was considered, the effect on the results would be negligible as there is no refrigerant leakage from domestic refrigerators and the electricity consumed per litre of beer during the assumed short-term refrigeration would be small; and

- glasses or other containers from which the consumer may drink the beer as these will also be used for other purposes.

\subsection{Data and assumptions}

Primary production data have been obtained from a beer manufacturer. This includes the materials and energy used for the production of beer as well as transport modes and distances along the supply chain. Background data have been sourced from the CCaLC (2013), Ecoinvent (2010), ILCD (2010) and $\mathrm{GaBi}$ (PE International 2010) databases. Where relevant, the data have been adapted to reflect the UK energy mix. Costs have been obtained from various sources, including the literature and market analyses. More details on the inventory data and their sources for each life cycle stage are provided in the next sections.

\subsubsection{Raw materials}

As shown in Table 1, the main ingredients for beer production are barley, hops, water and yeast as well as carbon dioxide for carbonation. Auxiliary materials used during brewing such as sodium hydroxide, sulphuric acid, phosphoric acid and diatomaceous earth are also included in the analysis. Carbon dioxide emitted during beer fermentation is captured and liquefied; the life cycle inventory data for the latter have been obtained from the Ecoinvent (2010) database. The inventory data for all other raw and auxiliary materials are also from Ecoinvent. Life cycle inventory data for barley cultivated in the UK have not been available so that the average European data, sourced from Ecoinvent, have been used instead. This is appropriate as the UK imports barley from the EU (HMRC 2014). Inventory data for hops have not been available either so that barley data have been used as a proxy.

The costs of the raw materials given in Table 1 have been obtained from a number of sources, including DECC (2013), the UK Agriculture and Horticulture Development Board (HGCA 2013), Global Water Intelligence (2011) and commodity market analysis.

\subsubsection{Beer production and filling}

The beer production process begins with malted barley being crushed into a coarse powder known as grist. Malted barley is obtained by soaking and draining the barley grains to initiate germination of the seed. Germination activates enzymes which convert starch and proteins into sugars and amino acids (Palmer 1999). The grain is then dried in a kiln and stored for use in brewing. The grist is transferred to a large vessel known as a mash tun where it is mashed with hot water. The sugars in the malt dissolve in the water to produce liquor called sweet wort, which is boiled with hops in large vessels known as coppers. After filtration and cooling of the wort, it is then blended with yeast and put in a fermentation vessel where yeast metabolises sugars in the wort to produce alcohol and carbon dioxide. The time required for this process varies from a few days to around 10 days depending on the yeast strain, fermentation parameters and taste profile (Galitsky et al. 2003). The addition of carbon dioxide and filtration are then carried out before filling the beer in bottles and cans. The electricity, steam and compressed air consumed during the production and filling process are summarised in Table 2 for the different types of packaging considered in this study. UK electricity costs have been sourced from the EU energy portal (EU 2013); the cost of compressed air is from BCAS (2007).

\subsubsection{Packaging}

The packaging materials are summarised in Table 1. Beer in the UK is mainly sold in three packaging types and sizes: 0.331 glass bottles and 0.441 aluminium and steel cans. The glass bottles normally retail in multi-pack cardboard crates. The bottles are assumed to contain $85 \%$ recycled glass based on the UK situation for coloured container glass (British Glass 2007). Different percentages of recycled glass are also considered later in the paper to examine the effect of this parameter on the environmental impacts. The bottle tops are made from steel. The aluminium and steel cans are assumed to contain 48 and $62 \%$ of recycled metal, respectively (EAA 2008; Defra 2009). Allocation of impacts for material recycling has been 
Table 1 Inventory data for raw materials and packaging

\begin{tabular}{|c|c|c|}
\hline Inputs & $\begin{array}{l}\text { Amount per } \\
\text { litre of beer }\end{array}$ & $\begin{array}{l}\text { Cost per litre of } \\
\text { beer ( } £ \text { pence/l) }\end{array}$ \\
\hline \multicolumn{3}{|l|}{ Raw materials and auxiliaries ${ }^{a}$} \\
\hline Barley & $73 \mathrm{~g}$ & 1.15 \\
\hline Water (process) & 8.431 & 1.12 \\
\hline Hops & $1.3 \mathrm{~g}$ & 2.81 \\
\hline Yeast & $21 \mathrm{~g}$ & 0.64 \\
\hline Diatomaceous earth & $1.7 \mathrm{~g}$ & $5 \times 10^{-2}$ \\
\hline Sodium hydroxide $(50 \%)$ & $9 \mathrm{~g}$ & 0.27 \\
\hline Phosphoric acid (50 \%) & $2 \mathrm{~g}$ & 0.11 \\
\hline Sulphuric acid (63\%) & $2.5 \mathrm{~g}$ & $3.43 \times 10^{-2}$ \\
\hline Carbon dioxide (liquid) & $30 \mathrm{~g}$ & 0.22 \\
\hline Light fuel oil ${ }^{b}$ & 0.041 & 2.72 \\
\hline \multicolumn{3}{|l|}{ Packaging } \\
\hline Glass bottles $(0.331)$ & $691 \mathrm{~g}$ & 1.6 \\
\hline Bottle $(85 \% \text { recycled content })^{\mathrm{c}}$ & $636.4 \mathrm{~g}$ & $2.44 \times 10^{-3}$ \\
\hline Bottle top (steel) ${ }^{\mathrm{d}}$ & $6.1 \mathrm{~g}$ & 0.3 \\
\hline Multi-pack crate (cardboard) ${ }^{\mathrm{a}}$ & $48.5 \mathrm{~g}$ & \\
\hline Aluminium cans $(0.441)$ & $36 \mathrm{~g}$ & $2.7^{\mathrm{e}}$ \\
\hline Can body $(48 \% \text { recycled content })^{\mathrm{c}}$ & $29.9 \mathrm{~g}$ & - \\
\hline Can ends (100\% virgin aluminium alloy $)^{\mathrm{c}}$ & $6.1 \mathrm{~g}$ & \\
\hline Steel cans $(0.441)$ & $76.0 \mathrm{~g}$ & $1.0^{\mathrm{e}}$ \\
\hline Can body $(62 \% \text { recycled content })^{c}$ & $69.9 \mathrm{~g}$ & - \\
\hline Can end (100\% virgin aluminium alloy) ${ }^{c}$ & $6.1 \mathrm{~g}$ & \\
\hline
\end{tabular}

${ }^{\mathrm{a}}$ The quantities of materials and fuels are from manufacturer and life cycle inventory data are from Ecoinvent (2010)

${ }^{\mathrm{b}}$ Used to generate steam for the production process

${ }^{\mathrm{c}}$ Life cycle inventory data from the CCaLC (2013) database

${ }^{\mathrm{d}}$ Life cycle inventory data from the Gabi (PE International 2010) database

${ }^{\mathrm{e}}$ Includes all components of the can carried out according to the recycled content approach. This means that only the impacts from the virgin materials have been taken into account while the impacts from the recycled material are impact-free. This is appropriate, as the recycled content in the material and their respective recycling rates are the same in this case. However, the impacts from the recycling

Table 2 Electricity and other utilities used for beer production and filling

\begin{tabular}{lll}
\hline Inputs & $\begin{array}{l}\text { Amount per } \\
\text { litre of beer }\end{array}$ & $\begin{array}{l}\text { Cost per litre of } \\
\text { beer (£ pence/l) }\end{array}$ \\
\hline Electricity (bottles) $^{\mathrm{a}}$ & $0.121 \mathrm{kWh}$ & 0.93 \\
Electricity (cans) $^{\mathrm{a}}$ & $0.115 \mathrm{kWh}$ & 0.89 \\
Steam $^{\mathrm{C}}$ & $0.006 \mathrm{MJ}$ & - \\
Compressed air $^{\mathrm{a}}$ & $0.01 \mathrm{Nm}^{3}$ & 0.02 \\
\hline
\end{tabular}

${ }^{\mathrm{a}}$ The quantities of inputs are from manufacturer and life cycle inventory data are from Ecoinvent (2010). $\mathrm{Nm}^{3}$ : air volume at standard pressure and temperature

${ }^{\mathrm{b}}$ From light fuel oil listed as an auxiliary material in Table 1 process are considered and are added to the total impacts from packaging. Cost data for the packaging materials have been estimated based on recovered cullet, metal and cardboard prices sourced from WRAP (2014). The packaging costs do not include the costs of the manufacture of the bottles and cans because of a lack of data.

\subsubsection{Retail refrigeration}

For the base case, it is assumed that beer is stored at ambient conditions at the retailer. However, a certain proportion of beer is usually refrigerated and this is considered as part of the sensitivity analysis for the GWP as it mainly affects this impact. The following assumptions have been made for refrigeration (Tables 3 and 4):

- the refrigerant is R404 with the GWP of $3860 \mathrm{~kg} \mathrm{CO}_{2}$ eq./ $\mathrm{kg}$ (IPPC/TEAP 2005);

- refrigerant charge is estimated at $3.5 \mathrm{~kg} / \mathrm{kW}$ (DEFRA 2007; Tassou et al. 2008); 
Table 3 Electricity consumption during retail refrigeration

\begin{tabular}{lllllll}
\hline Packaging & $\begin{array}{l}\text { Display } \\
\text { cabinet type }^{\mathrm{a}}\end{array}$ & $\begin{array}{l}\text { Electricity consumption } \\
\left(\mathrm{kWh} / \mathrm{m}^{2} \cdot \text { day }\right)\end{array}$ & $\begin{array}{l}\text { Electricity } \\
\text { consumption } \\
\left(\mathrm{kWh} / \mathrm{m}^{2} \cdot \mathrm{h}\right)\end{array}$ & $\begin{array}{l}\text { Quantity of drink } \\
\left(\mathrm{l} / \mathrm{m}^{2} \mathrm{TDA}^{\mathrm{d}}\right)\end{array}$ & $\begin{array}{l}\text { Electricity consumption } \\
\text { per litre of beer }\end{array}$ & $\begin{array}{l}\mathrm{GWP} \\
(\mathrm{Wh} / \mathrm{l} \cdot \mathrm{h})\end{array}$ \\
\hline Glass bottle & $\mathrm{RVC} 3$ & 13.8 & 0.58 & 70.6 & 8.2 & 119 \\
Aluminium can & $\mathrm{RVC} 3$ & 13.8 & 0.58 & 106.9 & 5.4 & 78 \\
Steel can & RVC3 & 13.8 & 0.58 & 106.9 & 5.4 & 78 \\
\hline
\end{tabular}

${ }^{a}$ RVC3: remote condensing unit, vertical, chilled

${ }^{\mathrm{b}}$ Data from Tassou et al. (2008)

${ }^{\mathrm{c}}$ Estimated by dividing the total volume of beer in the refrigerated display unit ( 3171 for glass bottles and 4801 for the aluminium and steel cans) by the TDA $\left(4.489 \mathrm{~m}^{2}\right)$

${ }^{\mathrm{d}} T D A$ : total display area

${ }^{\mathrm{e}}$ Estimated by dividing the electricity consumption of the refrigerated display unit by the volume of beer

- annual refrigerant leakage rate is assumed at $15 \%$ (Tassou et al. 2008; US EPA 2011);

- the total display area of the refrigeration unit is $4.489 \mathrm{~m}^{2}$ (BSI 2005);

- the drink is stored in the refrigeration unit for $24 \mathrm{~h}$ before it is sold;

- the GWP of UK electricity is $0.604 \mathrm{~kg} \mathrm{CO}_{2}$ eq. $/ \mathrm{kWh}$ (Ecoinvent 2010); and

- the cost of electricity is $£ 0.077$ per kWh (DECC 2014a).

\subsubsection{Waste management}

As shown in Table 5, all relevant waste streams have been considered, including effluents from the brewery and postconsumer waste packaging. The effluents from the brewery are treated in a wastewater treatment plant; for disposal of waste packaging, the average UK waste management options have been assumed. Note that, unlike in some countries, beer glass bottles are non-returnable in the UK. Landfill costs have been sourced from Hogg (2012) while wastewater treatment costs have been estimated based on data from Global Water
Intelligence (2011). Costs of recycling are included in the costs of packaging materials (WRAP 2011).

\subsubsection{Transport}

The transport modes and distances along the supply chain are shown in Table 6. The transport distance for the barley $(200 \mathrm{~km})$ has been provided by the manufacturer. In the absence of transport data for the other raw materials, they are also assumed to be transported to the same distance as barley. A distance of $100 \mathrm{~km}$ has been assumed for the delivery of beer to retailers. Transport costs for the raw materials are assumed to be included in the costs shown in Table 1. For transport of the packaging materials to the brewery and the beer to retailers, the cost analysis is based on the amount of fuel consumed, which has been estimated from the LCA model based on the distances. The cost of fuel (diesel) is assumed at $£ 1.13 / 1$ (EU 2013).

\subsubsection{Data quality and uncertainty}

To assess the uncertainty in the data and results, a data quality assessment has been carried out following the CCaLC (2014)
Table 4 Refrigerant leakage during retail refrigeration

\begin{tabular}{lllll}
\hline Packaging & $\begin{array}{l}\text { Volume of beer } \\
\text { chilled }^{\mathrm{a}}(1 / \text { year })\end{array}$ & $\begin{array}{l}\text { Refrigerant losses } \\
\text { (kg/year) }\end{array}$ & $\begin{array}{l}\text { Refrigerant losses per } \\
\text { litre of beer }^{\mathrm{c}}(\mathrm{mg} / \mathrm{l} \text { day })\end{array}$ & $\begin{array}{l}\mathrm{GWP}^{\mathrm{d}} \text { per litre } \\
\text { of beer }(\mathrm{g} / \mathrm{l})\end{array}$ \\
\hline Glass $(0.33$ 1) & 115,705 & 1.05 & 9 & 34.74 \\
Aluminium $(0.44$ 1) & 175,200 & 1.05 & 6 & 23.16 \\
Steel (0.44 1) & 175,200 & 1.05 & 6 & 23.16 \\
\hline
\end{tabular}

${ }^{\text {a }}$ Assuming 3171 for the glass bottles and 4801 for the aluminium and steel cans in the refrigeration unit; see note c in Table 3

${ }^{\mathrm{b}}$ Estimated by multiplying the annual refrigerant losses $(15 \%)$ by the refrigerant charge $(3.5 \mathrm{~kg} / \mathrm{kW})$ and the power of the refrigeration unit $(2 \mathrm{~kW})$

${ }^{\mathrm{c}}$ Estimated by dividing the annual refrigerant losses by the total volume of beer cooled annually

${ }^{\mathrm{d}}$ Estimated by multiplying the refrigerant losses per litre per day by the GWP of R404A ( $3860 \mathrm{~kg} \mathrm{CO} 2$ eq./kg) 
Table 5 Waste management

\begin{tabular}{llll}
\hline Waste & Waste management option & $\begin{array}{l}\text { Amount per litre } \\
\text { of beer }(\mathrm{g} / \mathrm{l})\end{array}$ & $\begin{array}{l}\text { Cost per litre of } \\
\text { beer (£ pence/l) }\end{array}$ \\
\hline Glass bottles & $85 \%$ recycled, 15 \% landfilled & 95.5 & 0.36 \\
Steel bottle tops & $100 \%$ landfilled & 6.1 & 0.02 \\
Cardboard crates & $100 \%$ landfilled & 48.5 & 0.18 \\
Aluminium can (body) & $48 \%$ recycled, 52 \% landfilled & 17.3 & 0.08 \\
Aluminium can (ends) & $100 \%$ landfilled & 3.5 & - \\
Steel can (body) & $62 \%$ recycled, 38 \% landfilled & 26.8 & 0.11 \\
Steel can (ends) & $100 \%$ landfilled & 3.2 & - \\
Effluents from brewery & Wastewater treatment & 6997 & 1.17 \\
\hline
\end{tabular}

Life cycle inventory data are from the ILCD (2010) and Gabi (PE International 2010) databases

methodology, which is described in detail in Section S1 in the Electronic Supplementary Material. Based on the five criteria considered (data age, geographical origin, source, completeness and reproducibility, reliability and consistency), the LCA data quality is estimated to be high and the LCC data quality is medium. Therefore, the LCA results can be considered to have high and LCC findings medium certainty. For full details on the data quality assessment, see Section S2 in the Electronic Supplementary Material.

\section{Results and discussion}

GaBi 4.3 LCA software (PE International 2010) has been used to model the system and the CML 2001 (Guinée et al. 2001) impact assessment method has been followed to estimate environmental impacts. The following impact categories are considered: GWP, abiotic depletion potential (ADP), acidification potential (AP), eutrophication potential (EP), human toxicity potential (HTP), marine aquatic ecotoxicity potential (MAETP), freshwater aquatic ecotoxicity potential (FAETP), terrestrial ecotoxicity potential (TETP), ozone depletion potential (ODP), photochemical oxidants creation potential (POCP). In addition to the CML impact categories, the primary energy and water demand have also been estimated. These results are discussed below. They are presented first for the functional unit of 11 of beer, starting with the GWP in the next

Table 6 Transport modes and distances along the supply chain ${ }^{\mathrm{a}}$

\begin{tabular}{llll}
\hline Material & $\begin{array}{l}\text { Transport } \\
\text { mode }\end{array}$ & $\begin{array}{l}\text { Distance } \\
(\mathrm{km})\end{array}$ & $\begin{array}{l}\text { Cost per litre of } \\
\text { beer (£ pence/1) }\end{array}$ \\
\hline Raw and auxiliary materials & Truck (40 t) & 200 & $-{ }^{\mathrm{b}}$ \\
Packaging & Truck (32 t) & 200 & 0.20 \\
Beer (to retailers) & Truck (32 t) & 100 & 0.10 \\
Waste packaging & Truck (32 t) & 100 & 0.10 \\
\hline
\end{tabular}

${ }^{a}$ All life cycle inventory data for road transport are from the GaBi database (PE International 2010)

${ }^{\mathrm{b}}$ Transport costs included in the costs of raw materials (Table 1) section and followed by the other environmental impacts in section 3.2. These results are compared with other studies in section 3.3. Possibilities for reducing the impacts are explored in section 3.4 and the life cycle costs are discussed in section 3.5. Following this, the sectoral results based on the annual production of beer in the UK are discussed in Section 3.6.

\subsection{Global warming potential}

As shown in Fig. 3, the GWP of 11 of beer in glass bottles is estimated at $842 \mathrm{~g} \mathrm{CO}_{2}$ eq. The impact from beer in aluminium and steel cans is lower: 575 and $510 \mathrm{~g} \mathrm{CO}_{2}$ eq., respectively. As can also be observed from the figure, packaging is the major hotspot, contributing between $35 \%$ (for steel cans) and $55 \%$ (glass bottles). This is mainly due to $\mathrm{CO}_{2}$ emissions from the production of packaging materials.

The contribution of raw materials and auxiliaries used in the beer manufacturing process ranges from $24 \%$ (for glass bottles) to $39 \%$ (for steel cans), mainly because of nitrous oxide emissions from barley cultivation and energy-intensive processing of barley malt. The share of different raw materials in the total GWP is shown in Fig. 4, with malted barley being the main contributor (57\%), followed by liquefied carbon dioxide (11\%) and light fuel oil (10\%). The contribution from carbon dioxide used for carbonation is due to the energy consumed for its purification and liquefaction. Because of the assumed biogenic origin of carbon dioxide, its release during the use stage is not considered in the analysis. In any case, the release of $\mathrm{CO}_{2}$ from beer is a complex issue which depends on many factors, including beer temperature (which affects the solubility of $\mathrm{CO}_{2}$ ) and whether it is drank immediately after opening or later (Tran et al. undated). Therefore, even if the origin of $\mathrm{CO}_{2}$ was from fossil sources, it would not be possible to determine with any accuracy its amount released from beer during consumption.

As also indicated in Fig. 3, beer production causes between $9 \%$ (bottle) and $14 \%$ (steel can) of the GWP, mainly because of electricity used in the process. Note that the biogenic carbon dioxide released during the fermentation of beer is not 
Fig. 3 Global warming potential (GWP) of beer for different packaging, also showing the contribution of different life cycle stages

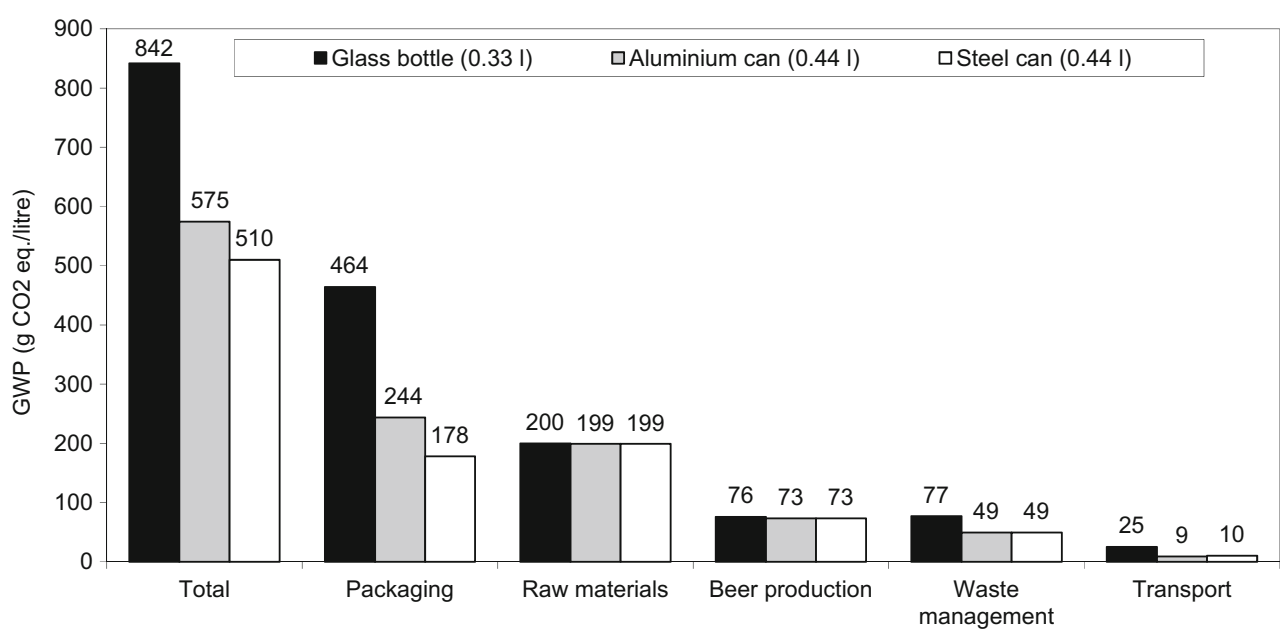

considered. The rest of the GWP is due to waste management (9-10\%) and transport (2-3\%).

\subsubsection{Effect of refrigerated storage on the GWP}

As mentioned earlier, in the base case we assume that beer is not refrigerated at retailer. However, a certain proportion of beer is always refrigerated at UK retailers for consumer convenience. Therefore, this section considers the effect of refrigerated storage at retailer. The focus is on the GWP as this impact is likely to be affected most, mainly because of electricity consumption during refrigeration and refrigerant leakage. Since beer bottles are typically refrigerated as single bottles without the secondary packaging (cardboard crate), this packaging is excluded from consideration in this case.
The results in Fig. 5 indicate that refrigerated retail storage adds between $15 \%$ (aluminium can) and $18 \%$ (bottle, without secondary packaging) to the total GWP of beer. This is based on the data in Table 3: during the assumed 1-day storage, electricity used to cool beer in bottles generates $119 \mathrm{~g}$ $\mathrm{CO}_{2}$ eq. and for that in cans $78 \mathrm{~g} \mathrm{CO}_{2}$ eq./ $/ 1$ of beer. The refrigerant leakage adds a further 35 and $23 \mathrm{~g} \mathrm{CO}_{2}$ eq./1, respectively (Table 4), increasing the total GWP of bottled beer from $722 \mathrm{~g} \mathrm{CO}_{2}$ eq./1 (without secondary packaging, see Fig. 6) to $876 \mathrm{~g} \mathrm{CO}_{2}$ eq./1 (Fig. 5). The impact from canned beer goes up from 575 to $676 \mathrm{~g} \mathrm{CO}_{2}$ eq./1 for aluminium and from 501 to $611 \mathrm{~g} \mathrm{CO}_{2}$ eq./1 for steel cans. Therefore, retail refrigeration has a significant effect on the GWP and should be minimised. Instead, it would be better for consumers to chill the beer at home for a short time before consumption (an hour is normally sufficient, with canned beer cooling faster than bottled) since domestic refrigerators
Fig. 4 Contribution of raw materials and auxiliaries to the global warming potential

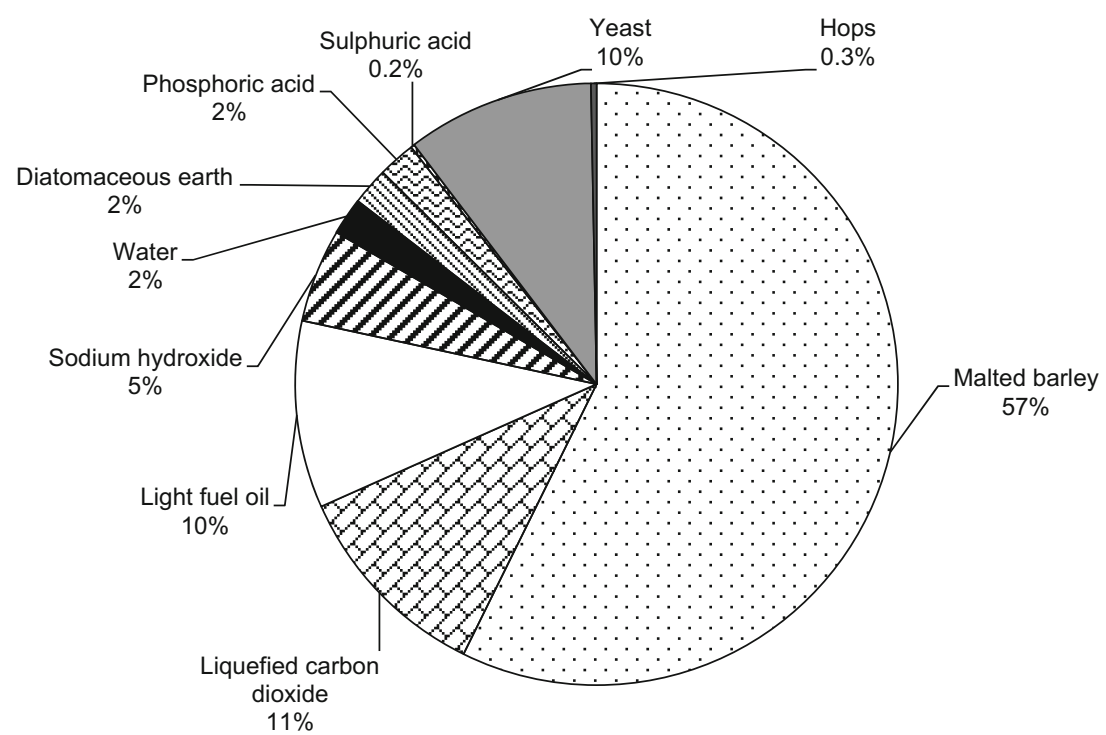


Fig. 5 Global warming potential of beer in different packaging including the contribution of refrigeration at retailer. [Retail includes impacts from electricity for refrigeration and refrigerant leakage as in Tables 3 and 4. Secondary packaging for glass bottles is excluded]

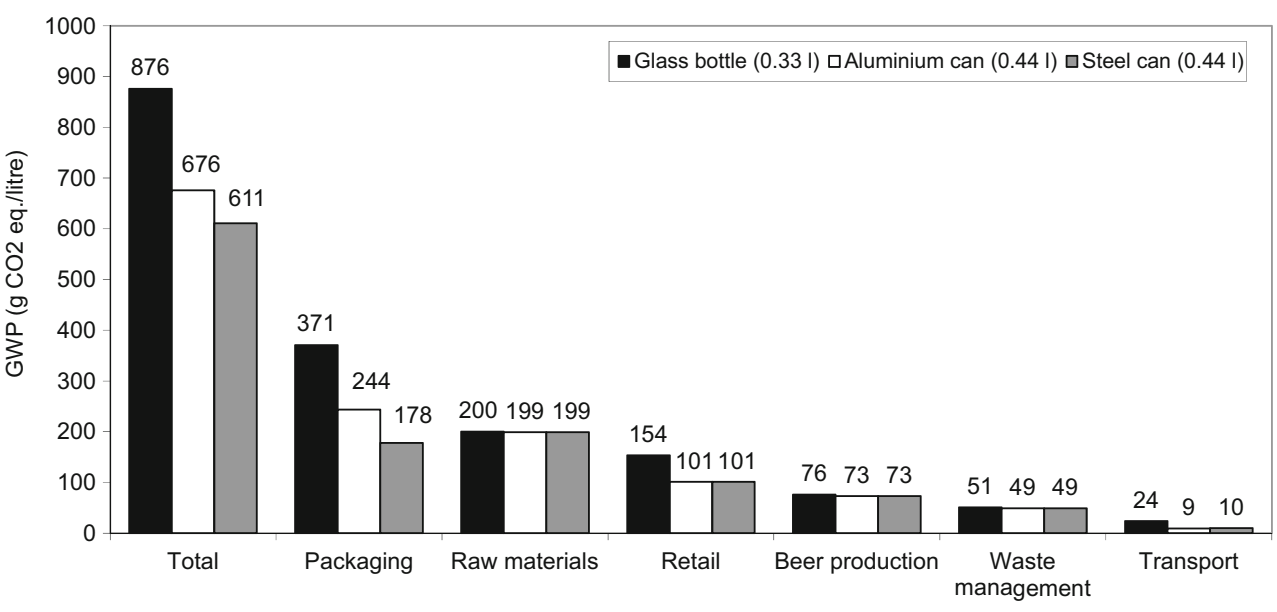

do not leak refrigerants and are more energy efficient, particularly if short-term storage is practiced.

\subsection{Other environmental impacts}

The results for the other environmental impacts are shown in Fig. 6. As mentioned earlier, the impacts of secondary packaging have not been assessed for the aluminium and steel cans (multi-pack plastic rings) because of a lack of data. Therefore, in order to compare the impacts of beer in different packaging on an equivalent basis, the impacts from beer in glass bottles are shown for two cases: with and without the secondary packaging (multi-pack cardboard crate). For completeness, the results are also shown for the GWP.
As can be observed from Fig. 6, beer packaged in the steel can has the lowest impacts for five out of 12 impact categories: PED, ADP, AP, MAETP and FAETP. Beer in the aluminium can is the best option for ODP and POCP but it also has the highest HTP and MAETP. The latter two are five and three times higher, respectively, than for the next best option, beer in the steel can. HTP is due to emissions of polyaromatic hydrocarbons from manufacturing of aluminium cans, while MAETP is mainly from hydrogen fluoride emissions, also from the can manufacturing process. The glass bottle, on the other hand, is the best option for the HTP but least favourable for eight impact categories (in addition to the GWP): PED, ADP, AP, EP, FAETP, TETP, ODP and POCP. This is regardless of whether the secondary packaging is

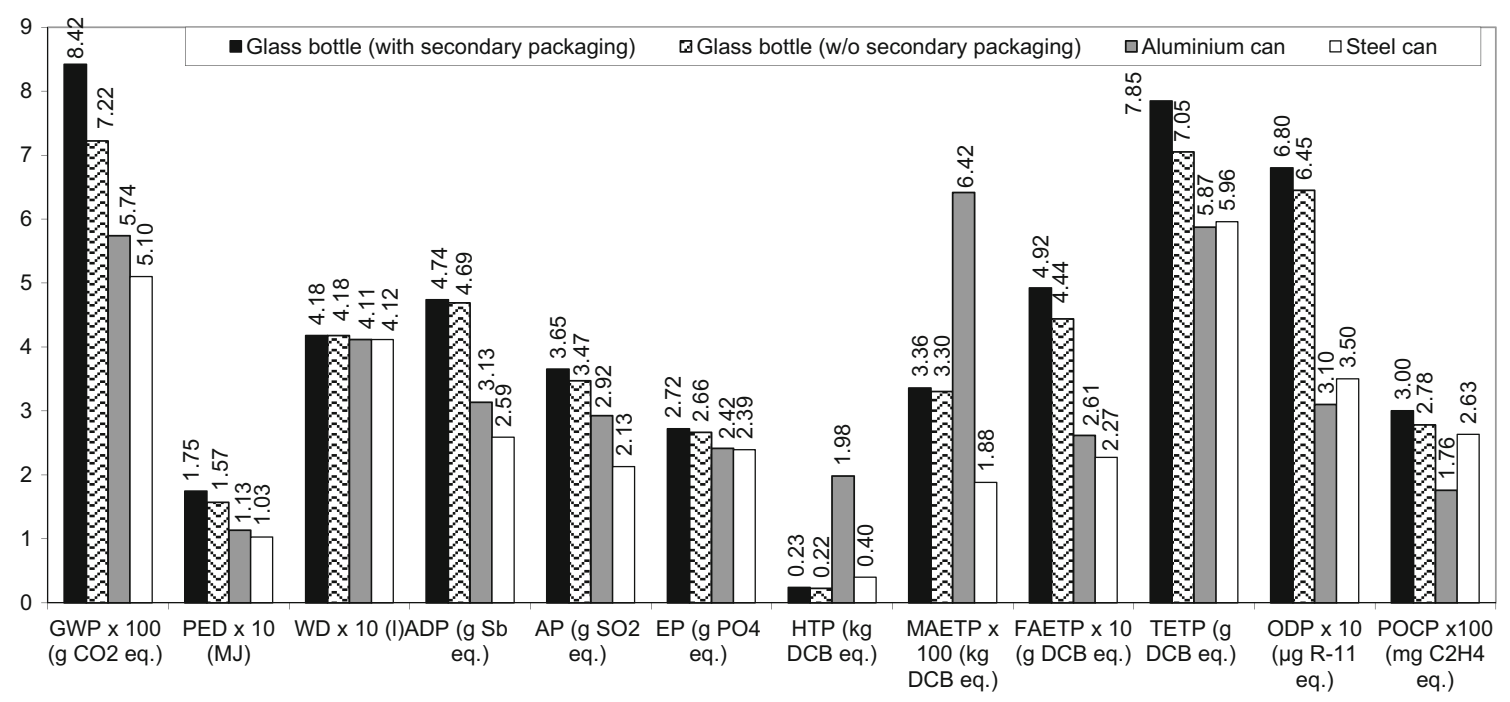

Fig. 6 Environmental impacts of beer for different packaging options. [All impacts expressed per 11 of beer. PED primary energy demand, WD water demand, $A D P$ abiotic depletion potential, $A P$ acidification potential, EP eutrophication potential, HTP human toxicity potential, $M A E T P$ marine aquatic ecotoxicity potential, FAETP freshwater aquatic ecotoxicity potential, TETP terrestrial ecotoxicity potential, $O D P$ ozone depletion potential, $P O C P$ photochemical oxidants creation potential. $D C B$ dichlorobenzene. The scaled values should be multiplied with the factor shown in brackets to obtain the original values] 
considered or not. The impacts from bottled beer without the secondary packaging are lower by between $1 \%$ (depletion of elements) and $14 \%$ (GWP). There is little difference between the packaging options with respect to water demand as the vast majority of water is used for beer rather than production of packaging.

The relative contributions to the impacts from different life cycle stages are shown in Fig. 7(a-c) for the three packaging options. The raw materials and packaging are the main hotspots for the beer for all three options. The raw materials contribute on average $47 \%$ (bottles) to $63 \%$ (steel cans) and the packaging from $19 \%$ (steel cans) to $46 \%$ (bottles) to the impacts. For the beer in steel cans, beer production is also a major contributor to POCP, accounting for $57 \%$ of this category. This is mainly due to nitrogen oxide and sulphur dioxide emissions in the life cycle of electricity used to produce steel.
Fig. 7 Contribution of different life cycle stages to the environmental impacts of beer in different packaging
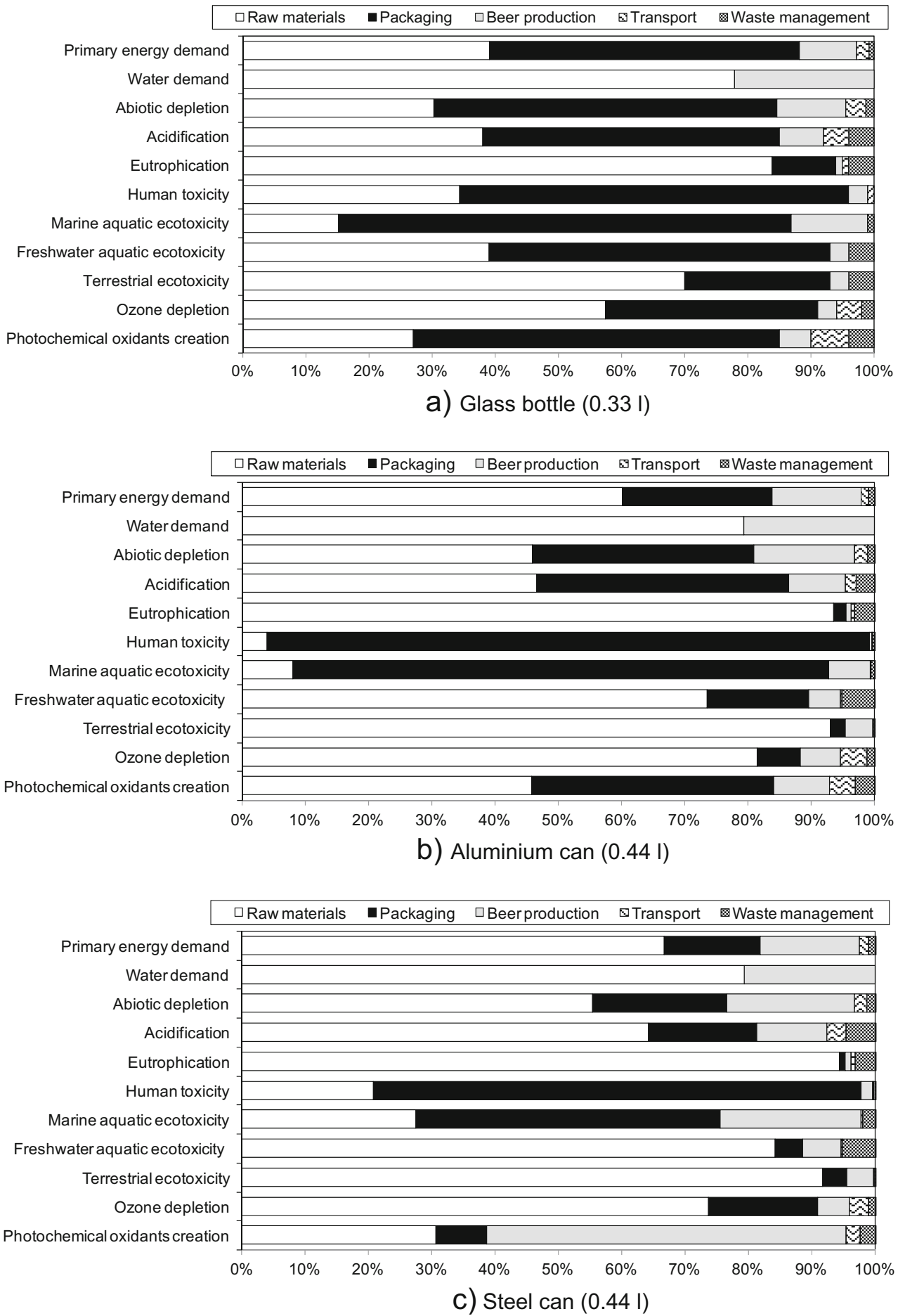
The contribution to the impacts of waste management and transport is small across the packaging types $(\sim 1 \%)$.

\subsection{Comparison of impacts with other studies}

As discussed in the "Introduction", a number of studies have been considered life cycle environmental impacts of beer produced in different parts of the world. Some of these are compared to the impacts estimated in current study. However, the comparison is only possible for a limited number of studies because of different life cycle impact methods used by different authors.

For the GWP, only four studies estimated the results according to the CML method and these are compared to the current study in Fig. 8. As can be observed, the results range widely across the studies, from $400-1475 \mathrm{~g} \mathrm{CO}_{2}$ eq./1 of beer. With the GWP values between 510 and $876 \mathrm{~g} \mathrm{CO}_{2}$ eq./l, the estimates in the present study fall well within this range. The variations in the results reported in different studies are due to various factors, including different geographical locations, packaging types and recycling rates, processes included in the analyses, transport modes and distances in the supply chain as well as allocation methods. Notwithstanding these differences, all studies found that the manufacture of packaging and raw materials are key contributors to the GWP, accounting for $18-78 \%$ and $6-42 \%$ of the total, respectively. By comparison, in the current study packaging is found to contribute between 19 and $46 \%$ and the raw materials 47 and $63 \%$.

Comparison of the other impacts with the literature is more constrained as only one study used the CML method (Narayanaswamy et al. 2004) to estimate the impacts. As can be observed in Fig. 9, there is a reasonably good agreement (despite the influencing factors mentioned above) in the results except for the AP which is higher in the study by Narayanaswamy et al. Since the results in the latter are provided only in an aggregated form, it is not possible to discern the reasons for this difference. Another significant difference can be noticed for the HTP, particularly for the beer in aluminium cans estimated in the current study. As discussed earlier, the HTP is particularly high due to emissions of polyaromatic hydrocarbons from manufacturing of cans; Narayanaswamy et al. only considered the impacts averaged for both glass bottles and aluminium cans so that the current-study results are more specific.

\subsection{Improvement opportunities}

The results from this study suggest that the main hotspots in the life cycle of beer are the raw materials and packaging. The greatest contributor to the impacts from the former is malted barley and from the latter, the glass bottle. Therefore, they should be targeted for enable greatest improvements in the supply chain.

There are many technological options that could be implemented to increase the efficiency of producing barley, including precision-farming to reduce the use of fertilisers and increased energy efficiency of drying the malted barley. The latter can be achieved by using a greater proportion of renewable energy, displacing fossil fuels in the barley drying process. However, because of a lack of disaggregated data on barley, it is not possible to quantify the effect of this on the environmental impacts. Instead, we turn our attention to improvement options related to glass bottles.

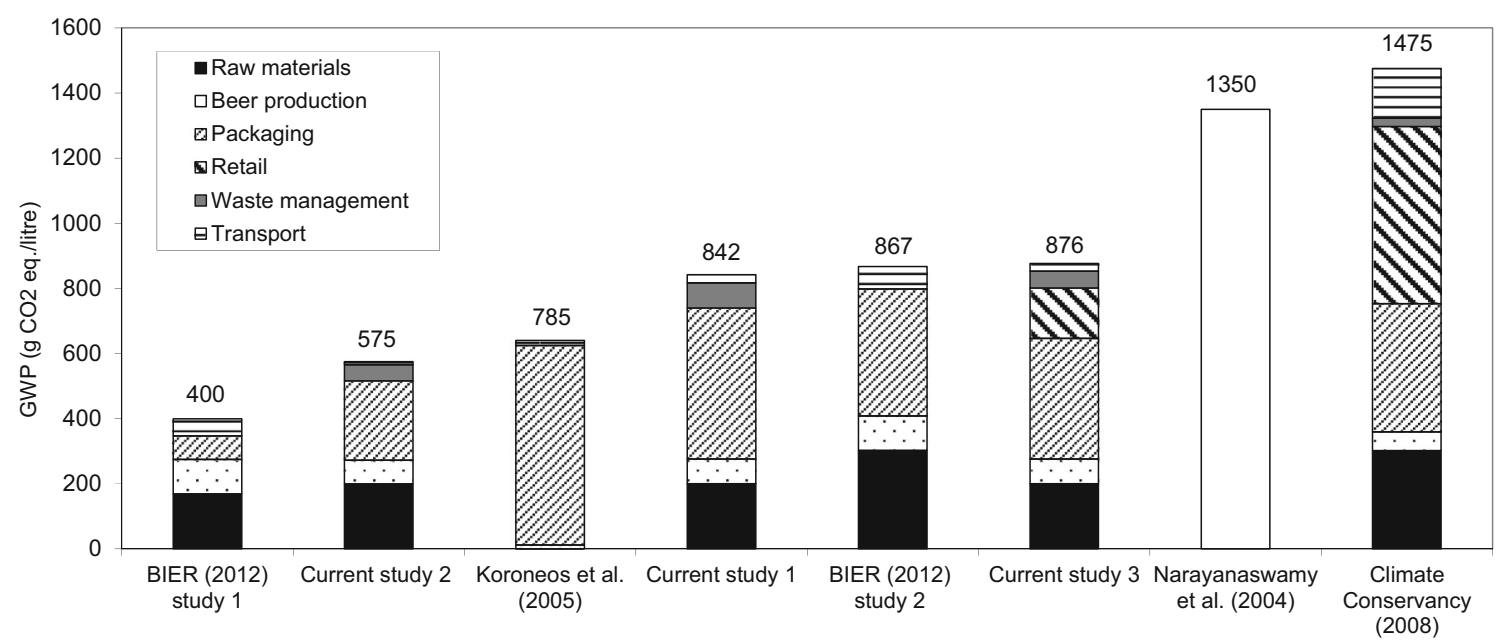

Fig. 8 Comparison of the global warming potential (GWP) with other studies [All results expressed per 11 of beer] BIER (2012) study 1 : European beer, glass bottle with $64 \%$ cullet content, 30 times reuse. Current study 1: glass bottle, includes multi-pack cardboard crate. Current study 2: aluminium can. Current study 3: glass bottle, includes refrigeration at retail. BIER (2012) study 2: North American beer, aluminium can with $52 \%$ recycling rate and $62 \%$ recycled content; Narayanaswamy et al. (2004): glass bottle and aluminium can (averaged), includes retail and use stages; only total impact available. Climate Conservancy (2008): glass bottle, includes retail and use stages] 


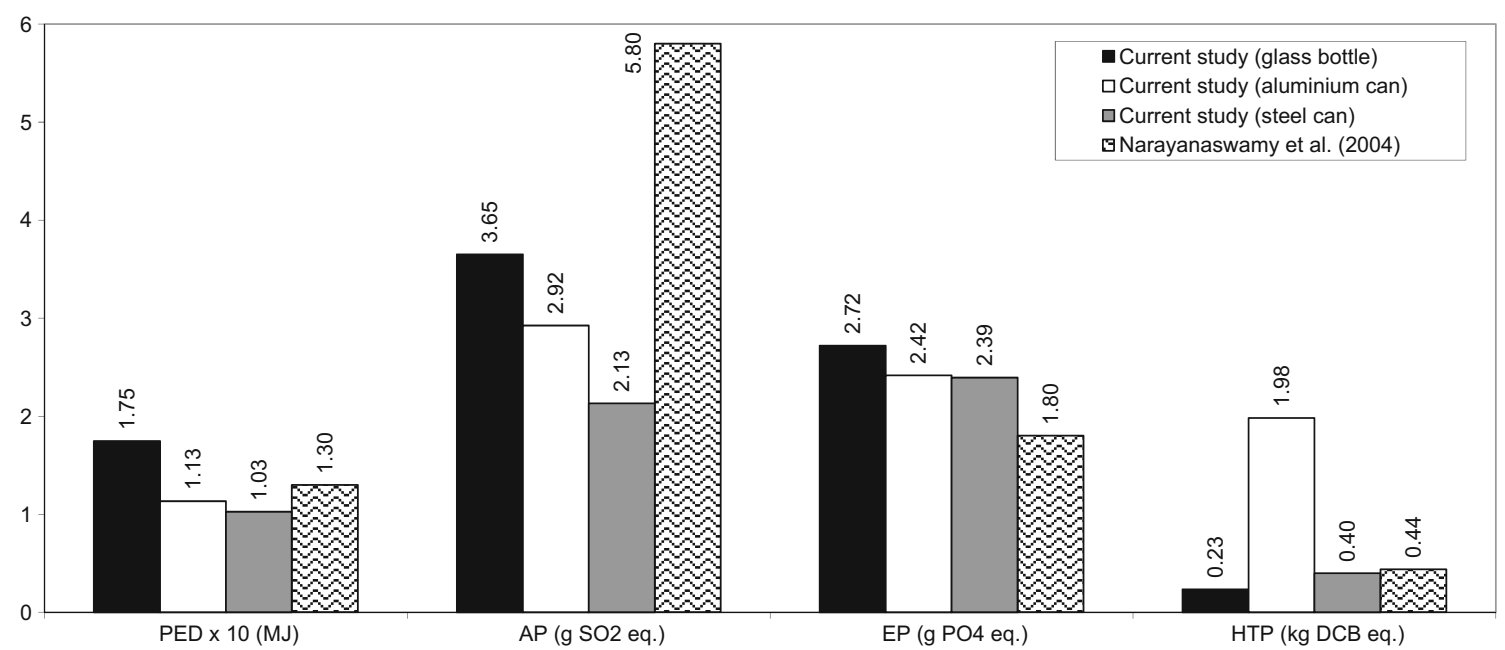

Fig. 9 Comparison of environmental impacts (other than the GWP) with other studies. [All results expressed per 11 of beer. For full names of the impact categories, see caption for Fig. 6. The values for PED should be multiplied with the factor shown in brackets to obtain the original values]

One of these would be to introduce returnable bottles in the UK. A study of returnable beer bottles in Portugal found that the reduction in impacts is dependent on the percentage of bottles returned and the number of times the bottle can be reused (Mata and Costa 2001). For example, at $50 \%$ reuse and up to six reuse cycles, the returnable bottle had lower impacts for most categories considered, except for eutrophication and ozone layer depletion. At $85 \%$ reuse, the contribution of returnable bottles was larger than that of non-returnable for all the environmental impacts. Another study based in the UK (Amienyo et al. 2013) considered reuse of glass bottles for carbonated soft drinks (CSD) and found that by reusing the bottle only once, the GWP of the CSD would be reduced by about $40 \%$. Further savings in the GWP could be achieved by increasing the number of reuses, although the benefits are not as significant after the second reuse and they gradually level off after about eight reuses. The results from that study also suggested that if the glass bottles were reused three times, the GWP of the drink packaged in glass bottles would be comparable to that packaged in aluminium cans. The study concluded that there was a clear case for reusing bottles between one and five times, depending on the economics. However, introducing reusable beer (or any other) bottles in the UK would require a completely new infrastructure, financial incentives and behavioural change, all of which are non-trivial. Currently, there are no plans to make this change in the UK.

In addition to returnable bottles, increasing the share of canned beer could be considered as a measure to reduce the impacts of beer, particularly steel cans, as they have lower impacts than glass bottles and aluminium packaging (see Fig. 6). The use of steel cans would lead to a reduction in most impacts, ranging from $12 \%$ for the EP and POCP to $54 \%$ for the FAETP; the GWP would be lower by $39 \%$. However, the HTP would increase by $41 \%$ and, if aluminium cans were used, by $88 \%$, also with the MAETP being $48 \%$ higher.
Consumer perception is also a factor that must be taken into account when considering a possible change of packaging, as many believe that bottled beer has better quality (Wilcox et al. 2013) while some believe that cans, particularly aluminium, may change the taste of beer or pose a health risk (Blanco et al. 2010). Furthermore, the economic and social impacts on the glass packaging industry would have to be weighed against the environmental benefits.

Therefore, we consider below the following two options which currently may be more feasible: increased recycled glass content and light-weighting of bottles.

\subsubsection{Recycled glass content}

In the UK beer sector, increasing the recycled content of glass bottles has been identified as a key initiative for improving environmental sustainability (Dalton 2011). To examine the effect of glass recycling on the environmental impacts, a range from 0 to $100 \%$ recycled glass content has been considered. From the results in Fig. 10, it can be observed that, for every $10 \%$ increase in the amount of recycled glass content, the GWP is reduced by around $3 \%$, amounting to a saving of $24 \mathrm{~g} \mathrm{CO}_{2}$ eq./1 of beer. The saving is due to lower energy consumption for bottle manufacturing and reduced amount of post-consumer waste sent to landfill. For the other environmental impact categories (except water demand), every $10 \%$ increase in the recycled glass content results in savings ranging from $0.5 \%$ (EP) to $2 \%$ (ADP). On the other hand, if no glass was recycled, the GWP would be $19.5 \%$ higher than currently (at $85 \%$ recycled content).

\subsubsection{Bottle light-weighting}

In addition to increasing the recycled content, light-weighting of glass bottles is another key focus area for the beverage 
- $0 \% \mathrm{RC} \quad \square 75 \% \mathrm{RC} \quad \square 85 \% \mathrm{RC}$ (base case) $\quad \square 95 \% \mathrm{RC} \quad \square 100 \% \mathrm{RC}$
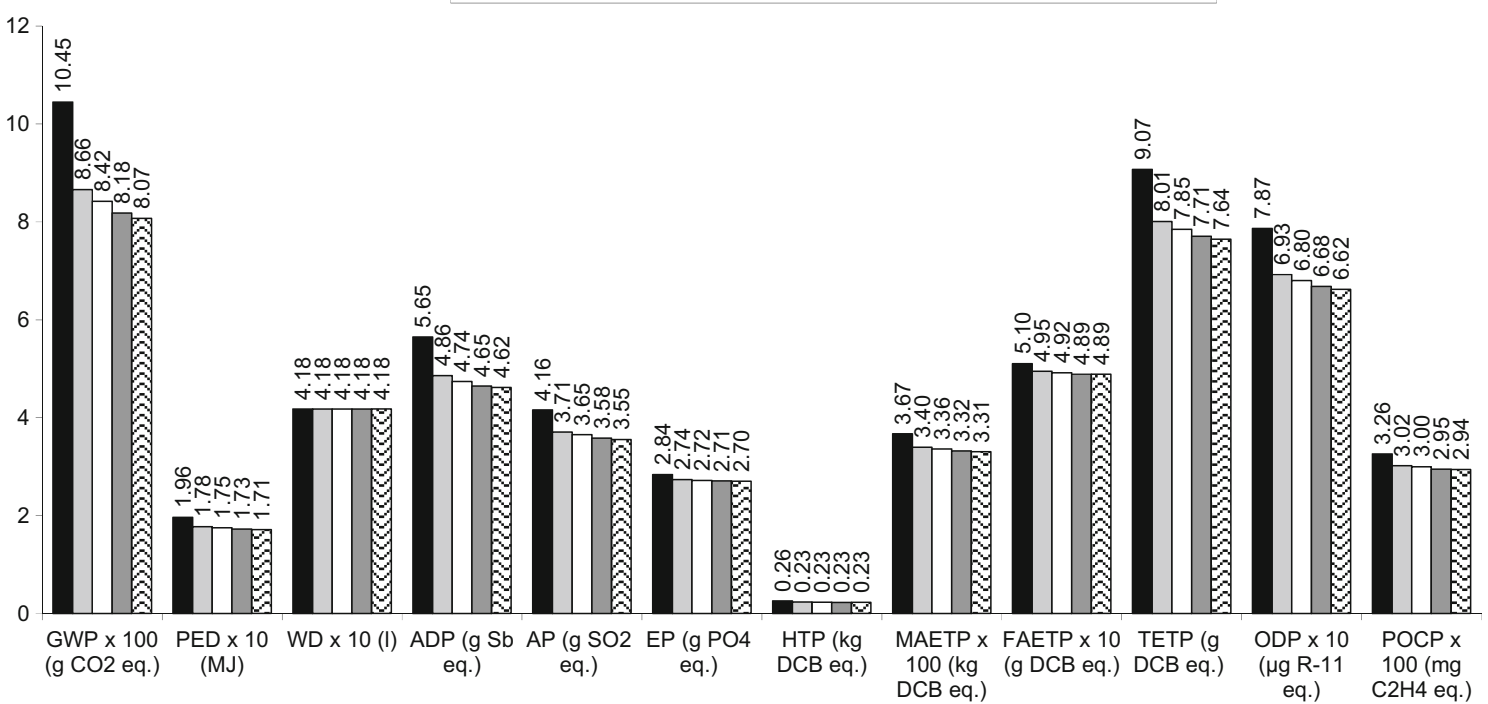

Fig. 10 Effect on environmental impacts of recycled content (RC) in glass bottles. [All impacts expressed per 11 of beer. Secondary packaging for glass bottles is included. For full names of the impact

categories, see caption for Fig. 6. The scaled values should be multiplied with the factor shown in brackets against the relevant impact to obtain the original values]

packaging sector (Cakebread 2011) and several multinational brewing companies, including $\mathrm{AB}$ InBev and Heineken, have reportedly achieved bottle weight reductions from 7 to $25 \%$ (WRAP 2011).

The results from this study suggest that reducing the weight of glass bottles by $10 \%$ results in the GWP savings of $5 \%$ or $40 \mathrm{~g} \mathrm{CO}_{2}$ eq./l of beer (Fig. 11). The savings arise from lower energy and material consumption for the manufacturing of glass bottles and reduced impacts from transport. For the other environmental impact categories (except water demand), every $10 \%$ increase in the recycled glass content results in savings ranging from $0.5 \%$ (EP) to $7 \%$ (MAETP).

\subsection{Life cycle costs}

As shown in Fig. 12, the life cycle costs of beer packaged in glass bottles and aluminium cans are close, estimated at 14.12 and 14.37 pence/l, respectively. This is because aluminium cans are more expensive to make but the costs of filling and waste management are higher for glass bottles so that the total

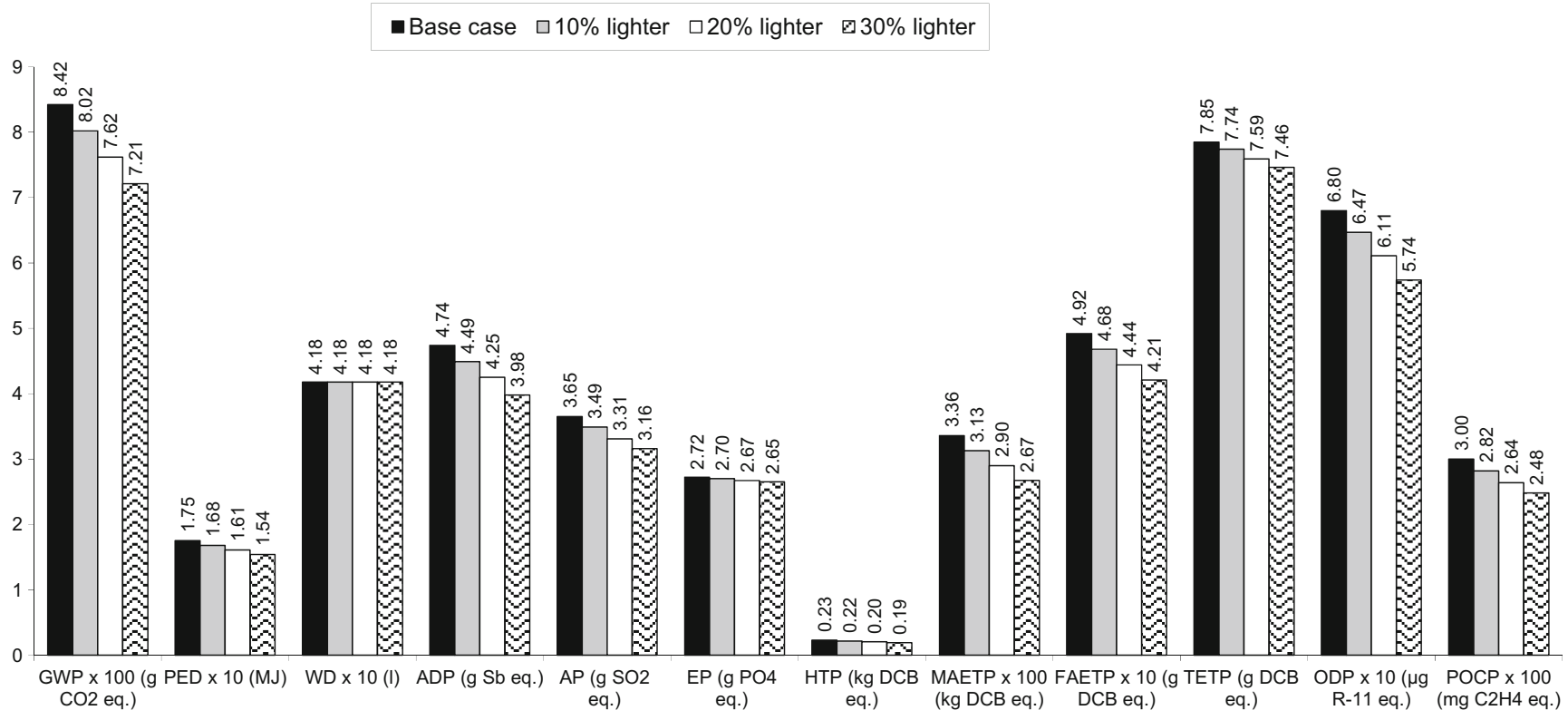

Fig. 11 Effect on environmental impacts of light-weighting of glass bottles. [All impacts expressed per 11 of beer. Secondary packaging for glass bottles is included. For full names of the impact categories, see

caption for Fig. 6 . The scaled values should be multiplied with the factor shown in brackets against the relevant impact to obtain the original values] 
Fig. 12 Life cycle costs of beer for different types of packaging. [The costs expressed per 11 of beer. Transport excludes the cost of transporting raw materials which are included in the Raw materials stage]

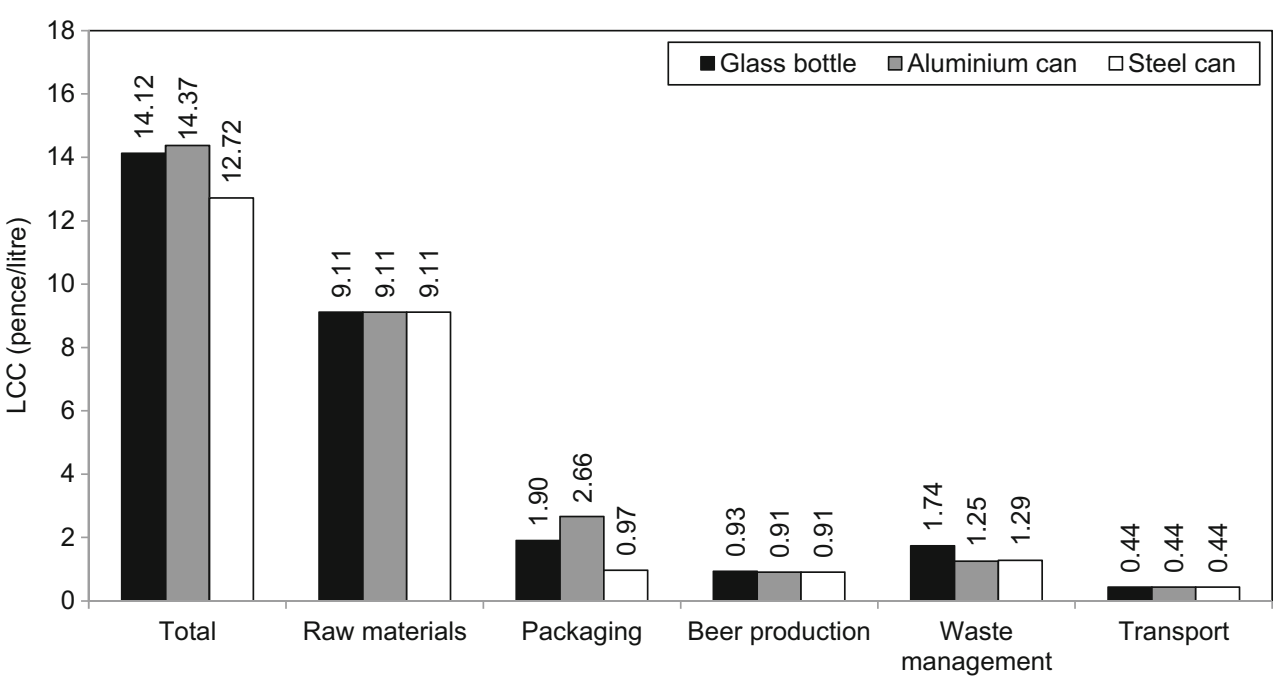

costs almost even out. The LCC of steel cans are lower, estimated at 12.72 pence/l. By comparison, a litre of beer retails in shops for $£ 1-£ 4$, depending on the type, quality, retailer and region, with an average retail price of $£ 1.83$ (HMRC 2013). Canned beer is typically cheaper than bottled, mainly for two reasons: beer quality and consumer perception, as mentioned earlier. However, the retail price of beer includes the government alcohol duty of 18.74 pence per each percentage of alcohol, so for a typical beer with $5 \%$ of alcohol, this amounts to 93.70 pence/l (UK Government 2014). The retail price also includes the VAT at $20 \%$ and an (unknown) retail mark-up. Thus, assuming the average LCC cost of 12.31 pence for bottled and canned beer (excluding post-consumer waste management), the total cost with the alcohol duty and VAT is around $£ 1.27 / 1$. This suggests a difference between the average retail price and total beer costs, with the alcohol duty and VAT included, of $£ 0.56 / 1$ of beer. However, these results should be used as a guide only since the cost data used here are generic and may not necessarily reflect the full costs. Furthermore, as mentioned earlier, the costs of packaging could be underestimated as they do include only the costs of packaging materials, excluding the costs of manufacturing the bottles and cans.

The main contributor to the LCC are the raw materials, adding between $63 \%$ (glass bottle and aluminium can) and $72 \%$ (steel can) to the total. This is mainly due to the costs of barley, hops, process water and light fuel oil which account for $86 \%$ of the costs of raw materials. The next largest cost contributor is packaging, ranging from $8 \%$ for steel cans, to $13 \%$ for glass bottles to $19 \%$ for aluminium cans. This is in agreement with the contribution to the environmental impacts, which are also largely due to the raw materials and the packaging (see section 3.2). The remaining costs are due to waste management (9-12\%), followed by beer production (6-7\%) and transport $(3 \%)$.

\subsection{Environmental impacts and costs of beer production and consumption in the $\mathrm{UK}$}

In this section, we discuss the environmental impacts and costs of beer produced and consumed in the UK. The impacts and costs have been estimated by scaling up the results for 11 of beer to the annual UK production.

As mentioned in the Introduction, around 4.5 bn litres of beer were produced in 2014 in the UK of which $14.6 \%$ was exported (Key Note 2014). In addition to the beer produced in the UK, $19.7 \%$ of beer was imported, with the overall importexport balance of around $5 \%$. Therefore, for simplicity, we consider all the beer produced in the UK to be consumed in the country, excluding both the imports and exports.

Out of the total volume of beer produced, around $2.26 \mathrm{bn}$ litres were sold in the UK off-trade market and 2.24 bn litres in the on-trade outlets (BBPA 2015). The majority of off-trade beer (around $72 \%$ ) is packaged in cans and the rest in glass bottles (Key Note 2010). There are no specific data on the market share between aluminium and steel cans used for beer but, according to Alupro (2015), $90 \%$ of drink cans in the UK are made of aluminium; therefore, this percentage is assumed here, with $10 \%$ of cans being made of steel.

For the on-trade beer, there are no figures on the volume sold as draft (from casks or kegs), bottled or canned. The only data available are related to the value of different types of on-trade beer which indicate that around $90 \%$ is sold as draft and the remaining $10 \%$ as bottled and canned beer (AB InBev and Bar-Expert, undated). Therefore, these percentages are assumed to correspond roughly to the volume of draft and packaged beer, respectively, for the on-trade market estimates. The casks or kegs used for the draft beer are not considered as they are reused many times. Beer refrigeration at on-trade outlets is also excluded because of a lack of data. Furthermore, there are no data on the share of bottled and 
canned beer in the on-trade market so that the same percentage is assumed as for the off-trade market (73\% canned and $27 \%$ bottled). For the canned beer, the same assumption is made with respect to the market share between the aluminium and steel cans as for the off-trade market ( 90 and $10 \%$, respectively).

The total annual environmental impacts and LCC of beer production and consumption in the UK are shown in Fig. 13. The annual life cycle costs are estimated at around $£ 553$ million, which represents $3.2 \%$ of the total beer market value of 17.12 bn estimated by Key Note (2014). Therefore, based on these estimates, the value added in the beer sector appears to be very significant.

Regarding the environmental impacts, water consumption is estimated at $1.853 \mathrm{bn} \mathrm{hl}$, or $5.3 \%$ of the actual amount of water consumed in the UK annually (3.51 trillion litres at 1501 per day per capita (Defra 2008)). For further context, this is equivalent to 74,120 Olympic-size swimming pools or $60 \%$ of the volume of Windermere, the largest lake in England. Primary energy consumption is equivalent to $0.56 \%$ of UK PED consumption of 8.62 million TJ (DECC 2104b). The total GWP amounts to 2.16 million tonnes of $\mathrm{CO}_{2}$ eq./year, contributing $0.85 \%$ to GHGs generated from consumption of UK-produced goods and services, estimated at $255 \mathrm{mt} \mathrm{CO}_{2}$ eq. (Defra 2013a). These findings are congruent with Garnett (2007) who estimated that beer contributed $0.96 \%$ to UK GHG emissions of $179 \mathrm{mt} \mathrm{CO}$ eq. in 2003/2004.

It is more difficult to put the other impacts into context but a comparison can be made with a previous study by the authors on the consumption of carbonated soft drinks (CSD) in the UK (Amienyo et al. 2013). The results in Fig. 14 show that the impacts from the annual beer consumption are on average $45 \%$ higher than from CSD, despite the consumption of the latter being $30 \%$ higher than that of beer. The difference in the GWP between beer and CSD is $31 \%$. However, the greatest difference is found for the freshwater and marine ecotoxicity potentials (92 and $80 \%$, respectively). This is mainly due to the higher impacts from the raw materials used for beer production than those used for CSD. On the other hand, the lowest difference between the two beverages is for the human toxicity $(11 \%)$. The reason for this is that the main source of this impact from CSD is the packaging while for the beer it is both the raw materials and the packaging — although much more packaging is used annually for the CSD than for beer (6.4 vs 2.5 bn litres), the total HTP from the beer production process and its packaging still outweigh the impacts from CSD packaging.

It can also be seen in Fig. 13 that the off-trade beer market is the main contributor to most impacts, including the HTP (86\%), MAETP (79\%) and GWP (67\%). It also contributes $58 \%$ to the life cycle costs. This is largely due to the packaging used in the off-trade sector, particularly aluminium cans which contribute $48-93 \%$ of the impacts from off-trade beer. Bottled beer is the second largest contributor to the off-trade beer impacts. In the on-trade sector, draft beer is the main contributor to most impacts (62-91\%), largely because of its high market share. The only exception is the HTP for which beer in aluminium cans is the main hotspot, contributing $58 \%$. As mentioned earlier, this is due to the emissions of polyaromatic hydrocarbons in the production of cans.

These results can provide useful evidence which could serve as a basis for the beer industry and government-led sustainability initiatives. An example of the latter is found for the carbonated soft drinks industry, with the Defra initiative aimed at gathering evidence for the development of a

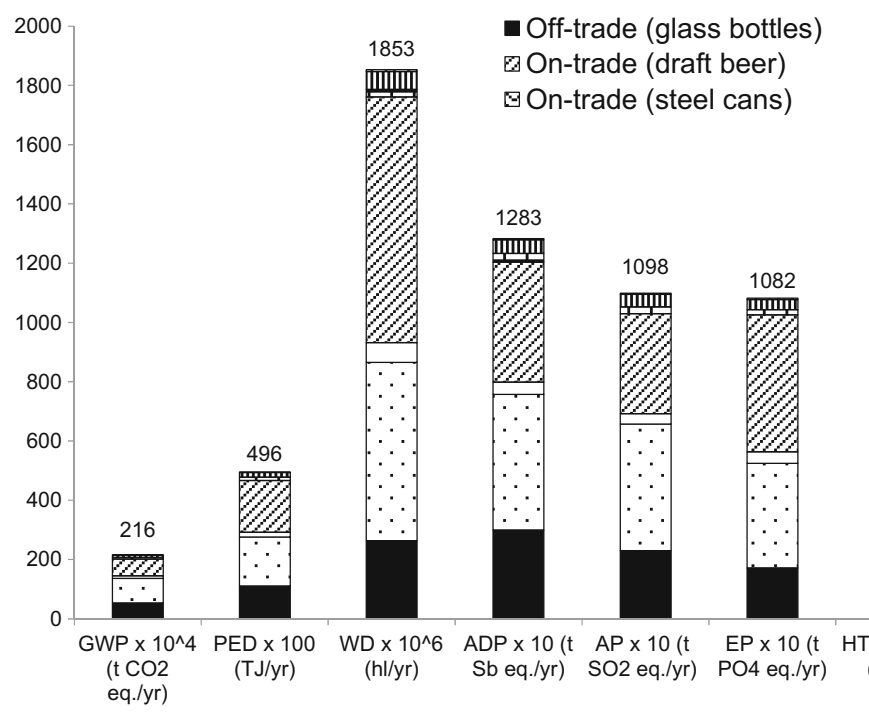

Fig. 13 Life cycle environmental impacts and costs of UK annual beer production and consumption. [The results refer to annual consumption of 4.5 bn litres of beer. For full names of the impact categories, see caption

\section{$\square$ Off-trade (aluminium cans) $\quad \square$ Off-trade (steel cans) ๓On-trade (glass bottles) m On-trade (aluminium cans)}

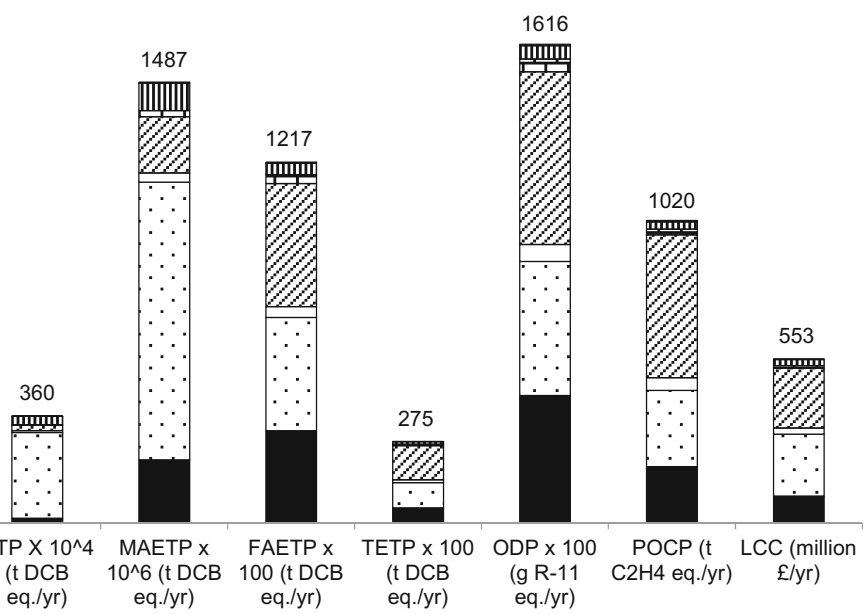

for Fig. 6. The scaled values should be multiplied with the factor shown in brackets against the relevant impact to obtain the original values] 


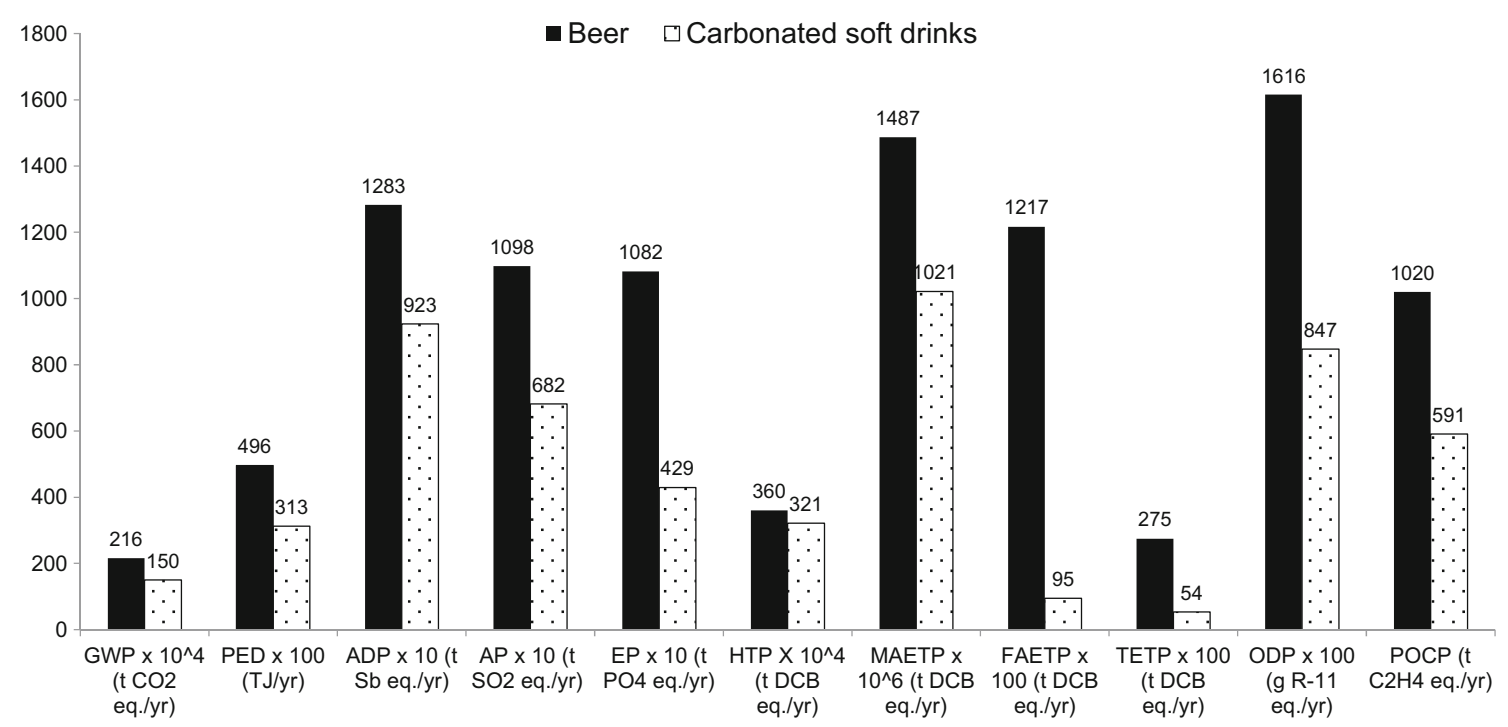

Fig. 14 Comparison of environmental impacts from UK consumption of beer and carbonated soft drinks. [The results refer to annual UK consumption of 4.5 bn litres of beer and 6.4 bn litres of soft carbonated drinks. The results for the latter are from Amienyo et al. (2013). For full

sustainability roadmap for the sector (Defra 2013b), which motivated our previous work on the impacts from that sector (Amienyo et al. 2013).

\section{Conclusions}

This paper has presented and discussed the life cycle environmental impacts and costs of beer production and consumption in the UK. The results have been estimated for two functional units: 11 of beer and the annual consumption of 4.5 bn litres. For example, it has been estimated that 11 of beer packaged in glass bottles consumes $17.5 \mathrm{MJ}$ of primary energy and generates $842 \mathrm{~g}$ of $\mathrm{CO}_{2}$ eq. emissions. By comparison, the beer in aluminium cans requires $11.3 \mathrm{MJ}$ of primary energy and emits $574 \mathrm{~g}$ of $\mathrm{CO}_{2}$ eq. while that in steel cans uses $10.3 \mathrm{MJ}$ of primary energy and produces $510 \mathrm{~g}$ of $\mathrm{CO}_{2}$ eq. Extrapolating these results to the annual consumption of beer in the UK gives the primary energy demand of over 49,600 TJ and the global warming potential of 2.16 million tonnes of $\mathrm{CO}_{2}$ eq. The former contributes $0.56 \%$ of the total UK energy demand and the latter $0.85 \%$ of GHG emissions from consumption of UK-produced goods and services.

The life cycle costs of beer in glass bottles and aluminium cans are close, estimated at 14.12 and 14.37 pence/l, respectively; for the beer in steel cans, the LCC are equivalent to 12.72 pence/l. Extrapolated to the annual beer consumption, the life cycle costs amount to around $£ 553$ million per year, or $3.2 \%$ of the total beer market value based on the retail selling price.

The results suggest that production of raw materials is the main hot spot in the life cycle of beer, contributing on average names of the impact categories, see caption for Fig. 6 . The scaled values should be multiplied with the factor shown in brackets against the relevant impact to obtain the original values.]

$47 \%$ (glass) to $63 \%$ (steel) to the total life cycle environmental impacts. For the life cycle costs, this contribution is estimated on average at $67 \%$ for the beer in all three types of packaging. Production of packaging is the next most significant contributor to the environmental impacts, adding on average $19 \%$ (steel) to $46 \%$ (glass) to the impacts. For the life cycle costs, production of packaging is also the second most significant contributor, accounting on average for $13 \%$, while waste management and beer production account for 10 and $7 \%$, respectively.

The findings also indicate that increasing the recycling and reducing the weight of glass bottles would lead to environmental benefits. For example, every $10 \%$ increase in the amount of recycled glass would reduce the GWP by about $3 \%$. This amounts to a saving of $24 \mathrm{~g} \mathrm{CO}_{2}$ eq./1 or around 16,700 tonnes of $\mathrm{CO}_{2}$ eq. annually. The savings for the other impacts range from $0.5 \%$ (EP) to $2 \%$ (ADP). Similarly, a $10 \%$ reduction in the weight of glass bottles would result in a $5 \%$ saving of $\mathrm{GHG}$ emissions ( $40 \mathrm{~g} \mathrm{CO}_{2}$ eq./1 or around 27 , 800 tonnes annually). Savings in other impact categories range from $1 \%$ (EP) to $7 \%$ (MAETP).

Further reductions in the impacts and costs could also be achieved by reducing consumption of beer. Currently, the UK consumes around 701 of beer per capita per year. A $10 \%$ decrease in the annual consumption, or 12 pints fewer per person, would lead to a $10 \%$ saving in environmental impacts and life cycle costs. For example, the GWP would be reduced by $22,000 \mathrm{t} \mathrm{CO}_{2}$ eq., primary energy demand by around $5000 \mathrm{TJ} /$ year and life cycle costs by $£ 55$ million. However, reducing consumption of alcohol (or anything else) is a complex issue as it requires a behavioural and cultural change. Nevertheless, in an attempt to limit alcohol intake for health 
reasons, the government recommends a maximum limit of 23 units of alcohol a day for women and 3-4 units for men. There is little evidence that these recommendations are being followed, but with a particular reference to beer, its consumption has gone down by $23 \%$ over the past 10 years. There could be many reasons for this, including a switch to other alcoholic drinks, but the implication of this is that the environmental impacts from beer consumption have also been reduced by a similar percentage over the past decade. However, they could have simply been transferred elsewhere owing to the rebound effect, either through increased consumption of other beverages or other compensatory activities. These are complex and interrelated issues for which there are no simple solutions - instead, they should be addressed as a part of an overall strategy to reduce consumption in all areas. While such a strategy will be difficult to sell to the consumer, and more critically to the political voter, it is difficult to see how the UK can reach its ambitious target of reducing the GHG emissions by $80 \%$ by 2050 , not to mention other environmental impacts, unless we address the issue of not only what we consume but also how much.

Acknowledgments This work has been funded by UK Engineering and Physical Sciences Research Council, EPSRC (grants no. EP/ F003501/1 and EP/K011820/1). This funding is gratefully acknowledged. The authors are also grateful to Dr Harish Jeswani at the University of Manchester for his help with some data collection and interpretation.

Open Access This article is distributed under the terms of the Creative Commons Attribution 4.0 International License (http:// creativecommons.org/licenses/by/4.0/), which permits unrestricted use, distribution, and reproduction in any medium, provided you give appropriate credit to the original author(s) and the source, provide a link to the Creative Commons license, and indicate if changes were made.

\section{References}

$\mathrm{AB}$ InBev and Bar-Expert (undated) A world of beer: market insights. $\mathrm{AB}$ Inbev and Bar-Expert. www.bar-expert.co.uk/admin_assets/content/ content_files/public/beer/market-insights.pdf

Alupro (2015) Aluminium packaging facts. the aluminium packaging recycling organisation, www.alupro.org.uk/aluminium-and-thecarbon-economy/aluminium-packaging-facts/.

Amienyo D, Gujba H, Stichnothe H, Azapagic A (2013) Life cycle environmental impacts of carbonated soft drinks. Int J Life Cycle Assess 18:77-79

BBPA (2015) UK quarterly beer barometer: moving annual total beer sales. British Beer and Pub Association, London

BCAS (2007) BCAS Fact Sheet No. 010: The Cost of Compressed Air. British Compressed Air Society, July 2007. www.bcas.org.uk/files/ pdffiles/16.pdf

BIER (2012) Research of the carbon footprint of beer. Beverage industry environmental roundtable, www.bieroundtable.com/files/Beer\% 20Final\%20DEP.pdf

Blanco CA, Sancho D, Caballero I (2010) Aluminum content of beers and silicon sequestering effects. Food Res Int 43:2432-2436
British Glass (2007) Sustainability Report 2007. www.britglass.org.uk/ Industry/Recycling.html

BSI (2005) Refrigerated display cabinets - part 2: classification, requirements and test conditions. British Standards Institution, London

BSI (2011) Publicly available specification PAS 2050:2011. Specification for the assessment of the life cycle greenhouse gas emissions of goods and services. British Standards Institution, London

Cakebread D (2011) Innovation in drinks packaging: a global insight. drinkspack 11: reducing the environmental impact of the drinks supply chain. Waste and Resources Action Programme (WRAP), London

CCaLC (2013) CCaLC v3.0 Software and Database. www.ccalc.org.uk

CCaLC (2014) CCaLC Manual. www.ccalc.org.uk

Climate Conservancy (2008) The carbon footprint of fat tire amber ale. The Climate Conservancy, Palo Alto, www.newbelgium.com/Files/ the-carbon-footprint-of-fat-tire-amber-ale-2008-public-dist-rfs.pdf

Cordella M, Tugnoli A, Spadoni G, Santarelli F, Zangrando T (2008) LCA of an Italian lager beer. Int J Life Cycle Assess 13:133-139

Dalton D (2011) Glass packaging and sustainability. drinkspack 11: reducing the environmental impact of the drinks supply chain. Waste and Resources Action Programme (WRAP), London

DECC (2013) Quarterly energy prices: March 2013. Department of Energy and Climate Change, London

DECC (2014) Quarterly energy prices: March 2014. Department of Energy and Climate Change, London

DECC (2104b) Energy Consumption in the UK (2014) Department of Energy and Climate Change, London https://www.gov.uk/ government/uploads/system/uploads/attachment_data/file/337452/ ecuk_chapter_1_overall_factsheet.pdf

Defra (2007) Market transformation programme, BNCR: 36: direct emission of refrigerant gases. Department for Environment, Food and Rural Affairs, London

Defra (2008) Future water: the government's water strategy for England. Department for Environment, Food and Rural Affairs, London

Defra (2009) Making the most of packaging: a strategy for a low-carbon economy. Department for Environment, Food and Rural Affairs, London

Defra (2013a) UK's carbon footprint 1997-2011. Department for Environment, Food and Rural Affairs, London

Defra (2013b) Evidence to support the development of a sustainability roadmap for soft drinks: phase 2 report. Department for Environment, Food and Rural Affairs, London

EAA (2008) Environmental profile report for the European aluminium industry. European Aluminium Association, Brussels

Ecoinvent (2010) Ecoinvent v2.2 Database. Dübendorf, Switzerland, Swiss Centre for Life Cycle Inventories. www.ecoinvent.ch

EU (2013) Europe's energy portal. European Commission, Brussels

Galitsky C, Martin N, Worrell E, Lehman B (2003) Energy efficiency improvement and cost saving opportunities for breweries. University of California, Berkeley

Garnett T (2007) The alcohol we drink and its contribution to the UK's greenhouse gas emissions. Food Climate Research Network

Global Water Intelligence (2011) Global Water Tariffs Continue Upward Trend. www.globalwaterintel.com/archive/12/9/market-profile/ global-water-tariffs-continue-upward-trend.html

Guinée JB, Gorrée M, Heijungs R, Huppes G, Kleijn R, van Oers L, Wegener Sleeswijk A, Suh S, Udo de Haes HA, de Bruijn H, van Duin R, Huijbregts MAJ (2001) Life cycle assessment, an operational guide to the ISO standards. Kluwer, Dordrecht

HGCA (2013) Market data centre. Agriculture and Horticulture Development Board, Kenilworth, http://data.hgca.com/archive/ future.asp

HMRC (2013) Alcohol factsheet 2012-2013. HM Revenue and Customs, UK, https://www.uktradeinfo.com/Statistics/Pages/ TaxAndDutyBulletins.aspx 
HMRC (2014) Volume of barley imported from EU countries into the United Kingdom (UK) from season 2002/03 to 2013/14. HM Revenue and Customs, UK, http://www.statista.com/statistics/ 298981/barley-uk-imports-from-eu-united-kingdom/

Hogg D (2012) Costs for Municipal waste Management in the EU: Final Report to the Directorate General Environment, European Commission. Eunomia Research and Consulting on behalf of Ecotec Research and Consulting

Hospido A, Moreira MT, Feijoo G (2005) Environmental analysis of beer production. Int J Agric Resour Gov Ecol 4(2):152-162

Hunkeler D, Lichtenvort K, Rebitzer G (eds) (2008) Environmental life cycle costing. SETAC, Pensacola

ILCD (2010) International life cycle database, European Joint Research Centre. http://lca.jrc.ec.europa.eu/lcainfohub/datasetArea.vm

IPPC/TEAP (2005) Special report: safeguarding the ozone layer and the global climate system. Intergovernmental Panel on Climate Change, Geneva, www.ipcc.ch/pdf/special-reports/ sroc/sroc full.pdf

ISO (2006a) ISO 14040 - Environmental management - life cycle assessment - principles and framework. International Organization for Standardization, Geneva

ISO (2006b) ISO 14044 - Environmental management - life cycle assessment - requirements and guidelines. International Organization for Standardization, Geneva

Jenkin N (2010) Wine \& climate change: packaging \& transport. Retail programme. Waste and Resources Action Programme (WRAP), London, www.climatechangeandwine.com/conferencias/conf8/8_ 1.pdf

Key Note (2009) Market Review 2009: Drinks Market. Key Note, Richmond upon Thames, UK

Key Note (2010) Packaging (Food \& Drink) Market Report 2010. Key Note, Richmond upon Thames, UK

Key Note (2014) Breweries and the Beer Market Update 2014. Key Note, Richmond upon Thames, UK

Kirin (2014) Global Beer Consumption by Country in 2012. Kirin Beer University Report, 28 January 2014. www.kirinholdings.co.jp/ english/news/2014/0108_01.html

Koroneos C, Roumbas G, Gabari Z, Papagiannidou E, Moussiopoulos N (2005) Life cycle assessment of beer production in Greece. J Clean Prod 13(4):433-439
Mata TM, Costa CAV (2001) Life cycle assessment of different reuse percentages for glass beer. Int J Life Cycle Assess 6(5):307-319

Narayanaswamy V, Berkel R, Altham J, McGregor M (2004) Application of life cycle assessment to enhance eco-efficiency of grains supply chains. Curtin University of Technology, Perth

Palmer J (1999) How to Brew. http://www.howtobrew.com/section1/ chapter $3 . h t m l$

PE International (2010) Gabi 4.3 LCA Software. www.gabi-software. com

Swarr T, Hunkeler D, Klöpffer W, Pesonen H-L, Ciroth A, Brent A, Pagan R (2011) Environmental life-cycle costing: a code of practice. Int J Life Cycle Assess 16(5):389-391

Takamoto Y, Mitani Y, Takashio M, Itoi K, Muroyama K (2004) Life cycle inventory analysis of a beer production process. Tech $\mathrm{Q}$ Master Brew Assoc Am 41(4):363-365

Talve S (2001) Life cycle assessment of a basic lager beer. Int J Life Cycle Assess 6:293-298

Tassou S, Hadawey A, Marriott D (2008) Greenhouse gas impacts of food retailing. Report for Department for Environment. Food and Rural Affairs, UK, http://randd.defra.gov.uk/Document.aspx?Document= FO0405_8189_FRP.pdf

Tran M, Wan C, Manyapu M, Scott A, Mendez A, Keifer O (undated) Effect of Changes in Temperature and the Handling of Beer on Amount of Carbon Dioxide Released when Poured. https:// scholarblogs.emory.edu/eurj/files/2014/05/CO2Paper_Final.pdf

UK Government (2014) Tax on Shopping and Services. https://www.gov. uk/tax-on-shopping/alcohol-tobacco

US EPA (2011) Ozone Layer Protection: Regulatory Programs - Leak Repair. www.epa.gov/ozone/title6/608/leak.html

Wilcox BR, Cruz GCY, Neal JA Jr (2013) Can consumers taste the difference between canned and bottled beers? J Culinary Sci Technol 11(3):286-297

WRAP (2011) Market Knowledge Portal. Waste and Resources Action Programme, (WRAP), London. www2.wrap.org.uk/recycling industry/market_information/market_knowledge_portal/index.html

WRAP (2014) Market Knowledge Portal. Waste and Resources Action Programme, (WRAP), London. www.wrap.org.uk/content/marketknowledge-portal-1 